О.І. Дорош', І.П. Цимбалюк-Волошинн,2, Х.І. Бодак', Р.С. Поліщук', А.І. Степанюк', О.І. Воробель', Л.Л. Скоропад', О.О. Трояновська', О.І. Козлова', А.М. Мих,,3, Л.П. Середич', О.В. Глинська' Прогрес у лікуванні гострої лімфобластної лейкемії: 25 років застосування міжнародних протоколів у відділенні дитячої гематології Західноукраїнського
спеціалізованого дитячого медичного центру

'КНП ЛОР «Західноукраїнський спеціалізований дитячий медичний центр», м. Львів, Україна ${ }^{2}$ Львівський національний медичний університет імені Данила Галицького, Україна ${ }^{3}$ Медичний центр Святої Параскеви, м. Львів, Україна

SOVREMENNAYA PEDIATRIYA.2018.8(96):22-36; doi 10.15574/SP.2018.96.22

Проаналізовано результати лікування за модифікованими програмами хіміотерапії міжнародної групи BFM 370 хворих на гостру лімфобластну лейкемію (ГЛЛ) віком від 0 до 18 р. з лютого 1993 р. до березня 2018 р. Показник безподійного виживання (event-free survival (EFS) для усієї вибірки пацієнтів становить 73,2\%. 143 (38,65\%) пацієнти отримали лікування на основі програм ALL-BFM 90/95 (група 1); 131 (35,41\%) хворий ALL IC-BFM'2002 (група 2); 88 (23,78\%) хворих — ALL IC-BFM 2009 (група 3). Діти віком до 1 року (8 осіб) лікувалися за програмами INTERFANT 99/06 (група 4). EFS у групі 1 становить 68,5\% із медіаною спостереження (MC) 220 місяців, за протоколом ALL IC-BFM 2002 - 77,6\% із MC 111 місяців, у групі 3 - 85,2\% при MC 39 місяців, у групі з програмами INTERFANT 99/06 - 12,5\% із MC 13,5 місяця. EFS для пацієнтів групи середнього ризику

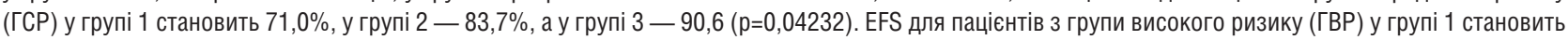
$50,0 \%$, у групі $2-55,6 \%$, у групі $3-73,9 \%$ ( $p=0,09653$ ). Кумулятивне виживання (overall survival (OS) у всій вибірці становить 78,0\%. 3агалом померло 73 (18,7\%) хворих. У 32 (43,8\%) осіб смерть мала зв'язок з терапією I лінії ГЛЛ, з них 11 (34,37\%) хворих померли від токсико-септичних ускладнень до досягнення ремісії ГЛЛ під час індукційної терапії, 19 (59,37\%) дітей - від ускладнень у ремісії і на різних етапах інтенсивної хіміотерапії, 1 хворий з ГВР — від посттрансплантаційних ускладнень, 1 пацієнт — на 160 міс. після досягнення ремісії від ффульмінантного перебігу вірусного гепатиту В. У 39 (53,42\%) хворих смерть настала у II гострому періоді внаслідок прогресування лейкемії та/або інфекційних ускладнень. Рецидиви ГЛЛ діагностовано у 53 (16,21\%) осіб. Безрецидивне виживання (disease-free survival (DFS) становить 83,2\%. Рідкісним віддаленим наслідком лікування ГЛЛ у дітей були вторинні злоякісні захворювання, які зареєстровано у 5 (1,35\%) дітей. Астроцитома, менінгіома та вторинна гостра мієлоїдна лейкемія (ГМЛ) успішно проліковані, олігодендрогліома та вторинний мієлодиспластичний синдром 3 транссрормацією у ГМЛ мали летальний наслідок. Алогенну трансплантацію стовбурових гемопоетичних клітин (ало-ТСГК) виконано 15 особам. Виявлено статистично достовірне покращання показників EFS при застосуванні програмної поліхіміотерапії ALL IC-BFM 2009, найгірші результати лікування були у дітей до 1-го року $(p<0,05)$. Лікування хворих з високої групи ризику (ГВР) та дітей першого року життя потребує подальшого пошуку шляхів підвищення ефективності терапії і зниження її токсичних ефектів.

Ключові слова: гостра лімфобластна лейкемія, діти, лікування, міжнародні протоколи.

\title{
Progress in the treatment of acute lymphoblastic leukemia: 25 years of application of international protocols in the Department of Pediatric Hematology of the Western Ukrainian Specialized Children's Medical Center
}

O. Dorosh', I. Tsymbalyuk-Voloshyn', Kh. Bodak', R. Polishchuk', A. Stepanyuk', O. Vorobel',

L. Skoropad', O. Troyanovska', , O. Kozlova', A. Myh ${ }^{1,3}$, L. Seredych' ${ }^{1}$, O. Hlynska'

'Lviv Regional Council Public Institution «Western Ukrainian Specialized Children's Medical Centre», Ukraine 2Danylo Halytskyy Lviv National Medical University, Ukraine

${ }^{3}$ Medical center of Saint Paraskevia, Lviv, Ukraine

The results of treatment for modified chemotherapy programs of the international BFM group from February 1993 to March 2018 in 370 patients with acute lymphoblastic leukemia (ALL) aged 0 to 18 years were analyzed. The event-free survival (EFS) indicator for the entire sample of patients is $73.2 \%$. $143(38.65 \%)$ patients received treatment based on programs ALL-BFM 90/95 (group 1); from November 2002 to June $2012-131$ (35.41\%) patients ALL IC-BFM 2002 (group 2); from June 2012 - 88 (23.78\%) patients - ALLIC-BFM2009 (group 3) correspondingly. Children under the age of 1 (8 persons) from August 2008 were treated according to INTERFANT'99/06 programs (group 4). EFS in group 1 is $68.0 \%$ with a median observation time (M0) for 220 months, in group $2-77.6 \%$ with MO 111 months, in group $3-85.2 \%$ with MO 39 months, in group $4-12.5 \%$ of M0 13.5 months. The statistically significant improvement of EFS indexes in group 3, the worst results in children under 1 year $(p<0.05)$. The EFS for middle-risk group (MR) patients in the 1st group was $71.0 \%$, in the 2 nd group $-83.7 \%$, and in the $3 r$ group $-90.6 \%(p=0.04232)$. The EFS for the high-risk group (HR) patients in the 1 st group was $50.0 \%$, in the 2 nd $-55.6 \%$ and in the 3 rd group $-73.9 \%(p=0.09653)$. The overall survival $(0 S)$ in the entire sample is $78.0 \%$. Totally 73 died $(18.7 \%)$. In $32(43.8 \%)$ people, death was associated with the therapy of the 1 st line of ALL, 11 of them (34.37\%) died of toxic-septic complications until the remission of ALL during induction therapy; 19 children (59.37\%) — from complications in 1st remission at different stages of intensive chemotherapy, 1 patient with HR from post-transplant complications, 1 patient - for 160 months. after reaching a remission from the fulminant course of viral hepatitis B. The 39 (53.42\%) patients, death occurred in the second acute period from the progression of leukemia and/or infectious complications. Relapse of ALL is diagnosed in $53(16.21 \%)$ people. Disease-free survival (DFS) is $83.2 \%$. A rare remote consequence of ALL treatment in children was secondary malignant diseases, which were registered in $5(1.35 \%)$ children. Astrocytoma, meningioma, secondary acute myeloid leukemia (AML) have been successfully treated, oligodendroglioma and secondary myelodysplastic syndrome with transformation in to AML was a reason of lethal consequence. 8 persons from the HR-group in the 1st remission had allo-BMT (abroad), including 2 patients — for whom alloBMT was a second therapeutic line for treatment of secondary AML. The statistically significant improvement in the EFS indices in the application of program polychemotherapy ALL IC-BFM 2009 was revealed, the worst results of treatment in children under 1 year $(p<0.05)$. Treatment of patients with high risk groups $(H R)$ and in children of the first year of life requires further searching for ways to improve the effectiveness of therapy, and reduce its toxic effects.

Key words: children, acute lymphoblastic leukemia, treatment, international protocols. 


\section{Прогресс в лечении острого лимфобластного лейкоза: 25 лет применения международных протоколов в отделении детской гематологии Западноукраинского специализированного детского медицинского центра

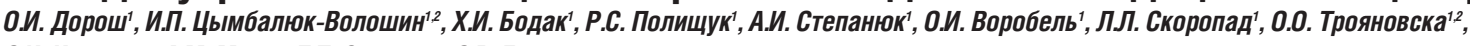 О.И. Козлова', А.М. Мых ${ }^{1,3}$, Л.П. Середич', О.В. Глинска' \\ 'КНП ЛОС «Западноукраинский специализированный детский медицинский центр», (КНП ЛОС ЗУСДМЦ), г. Львов,Украина ${ }^{2}$ Львовский национальный медицинский университет имени Данила Галицкого, Украина ${ }^{3}$ Медицинский центр Святой Параскевии, г. Львов, Украина}

Проанализированы результаты лечения согласно модифицированным программам химиотерапии международной группы BFM 370 больных острым лимфобластным лейкозом (ОЛЛ) в возрасте от 0 до 18 лет с февраля 1993 г. по март 2018 г. Показатель безсобытийного выживания (еvent-free survival (EFS) для всей выборки пациентов составляет 73,2\%. 143 (38,65\%) пациента получали лечение по программам ALL-BFM 90/95 (группа 1); 131 (35,41\%) больной - ALL IC-BFM 2002 (группа 2); 88 (23,78\%) больных - ALL IC-BFM 2009 (группа 3). Дети в возрасте до 1 года (8 человек) лечились в соответствии с программами INTERFANT 99/06 (группа 4). EFS в группе 1 составляет 68,5\% при медиане наблюдения (МН) 220 месяцев, по протоколу ALL IC-BFM 2002 - 77,6\% при MH 111 месяцев, в группе 3 - 85,2\% при MH 39 месяцев, в группе по программам INTERFANT 99/06 12,5\% при MH 13,5 месяцев. EFS для пациентов группы среднего риска (ГСР) в группе 1 составляет 71,0\%, в группе 2 - 83,7\%, а в группе 3 - 90,6\% ( $p=0,04232)$. EFS для пациентов группы высокого риска (ГВР) в группе 1 составляет 50,0\%, в группе $2-55,6 \%$, в группе $3-73,9 \%$ ( Кумулятивное выживание (overall survival (OS) по всей выборке составляет 78,0\%. Всего умерло 73 (18,7\%). у 32 (43,8\%) человек смерть связана с терапией І линии ОЛЛ, из них 11 (34,37\%) больных умерли от токсико-септических осложнений до достижения ремиссии ОЛЛ во время индукционной терапии; 19 (59,37\%) детей — от осложнений в ремиссии I на разных этапах интенсивной химиотерапии, 1 больной ГВР — от посттрансплантационных осложнений, 1 пациент - на 160 мес. после достижения ремиссии - вследствие фрульминантного течения вирусного гепатита В. У 39 (53,42\%) больных смерть наступила во II остром периоде от прогрессирования лейкемии и/или инфекционных осложнений. Рецидивы ОЛЛ диагностированы у 53 (16,21\%) человек. Безрецидивная выживаемость (disease-free survival (DFS) составляет 83,2\%. Редким отдаленным последствием лечения ОЛЛ у детей были вторичные злокачественные заболевания, зарегистрированные у 5 (1,35\%) детей. Астроцитома, менингиома и вторичная острая миелоидная лейкемия (ОМЛ) успешно пролечены. Олигодендроглиома и вторичный миелодиспластический синдром с трансформацией в ОМЛ завершились летальным исходом. Аллогенная трансплантация стволовых гемопоэтических клеток (алло-ТСГК) выполнена 15 больным. Определено статистически достоверное улучшение показателей ЕFS при применении программной полихимиотерапии ALL IC-BFM 2009, худшие результаты лечения наблюдались у детей до 1 года (р <0,05). Лечение больных ГВР и детей первого года жизни требует дальнейшего поиска путей повышения эффективности терапии и снижения ее токсических эффектов. Ключевые слова: острый лимфобластный лейкоз, дети, лечение, международные протоколы.

\section{Вступ}

3 відкриттям у вересні 1990 р. відділення гематології у Львівській обласній дитячій спеціалізованій клінічній лікарні (у 2009 р. перейменована на КЗ ЛОР ЗУСДМЦ) почався новий етап в історії вітчизняної гематології. Створення такого осередку ставило завдання збільшення чисельності вилікуваних дітей 3 гематоонкологічними захворюваннями, у тому числі хворих на гостру лейкемію, що становить 30,0-35,0\% серед злоякісних новоутворень дитячого віку, з них 80,0-90,0\% припадає на гостру лімфобластну лейкемію (ГЛЛ) [5,6,46,51,68,74,77,78]. Ще чверть століття тому від лейкеміі, яка вважалася невиліковною хворобою, українці одужували в поодиноких випадках. Нині ГЛЛ належить до тих недуг, які ефективно лікують в Україні.

За результатами сучасних багатоцентрових досліджень, у 75,0-90,0\% дітей з ГЛЛ, старших 1 року, досягається п'ятирічне виживання [52,65]. Однак у близько 10,0-20,0\% пацієнтів спостерігається рецидив хвороби. Серед них лише у третини є шанси вижити протягом багатьох років [5,7,9,18,21,32,63,65]. У до 10,0\% дітей причиною смерті є важкі інфекційні процеси, зумовлені агранулоцитозом, геморагічні та інші токсичні ускладнення [27].

У нашій країні з початку $90-$ х років минулого століття застосовується інтенсивна хіміоте- рапія, створена на основі програми ALL-BFM 90, яка сприяє значному поліпшенню результатів лікування ГЛЛ у дітей. За участі німецьких колег (професора Гюнтера Шеллонга з Університетської клініки м. Мюнстера та доктора Альфреда Рейтера з Вищої медичної школи м. Ганновера) у 1993 р. була створена Кооперативна група «Дитячі лейкемії та лімфоми України» (ДГЛЛУ). На основі протокольного лікування ALL-BFM 90/95 впроваджено модифіковані лікувальні протоколи Групи ВFM ГЛЛ-ДГЛЛУ 93/95 із відповідною діагностикою та стратифікацією до груп ризику. Відділення гематології та інтенсивної терапії ЗУСДМЦ є активним членом кооперативної групи ДГЛЛУ з часу іï заснування та дотримується усіх вимог стандартизованих протоколів.

Модифікація програмами ГЛЛ-ДГЛЛУ 93/95 порівняно з базовою полягала у: редукції дози метотрексату (MTX) у протоколі М до 1,0 г/м² замість 5,0 г/м²; у програмі ГЛЛ-ДГЛУ 95 діти групи низького ризику (ГНР) отримували лікування за протоколом Іа, коли застосовувалися лише два введення даунорубіцину. Загальний дизайн програм представлений на рис.1. Усіх хворих розділяли на 3 групи ризику: низький (ГНР), середній (ГСР) і високий (ГВР). У ГВР проводилося лікування відповідно до терапевтичного плану для хворих 


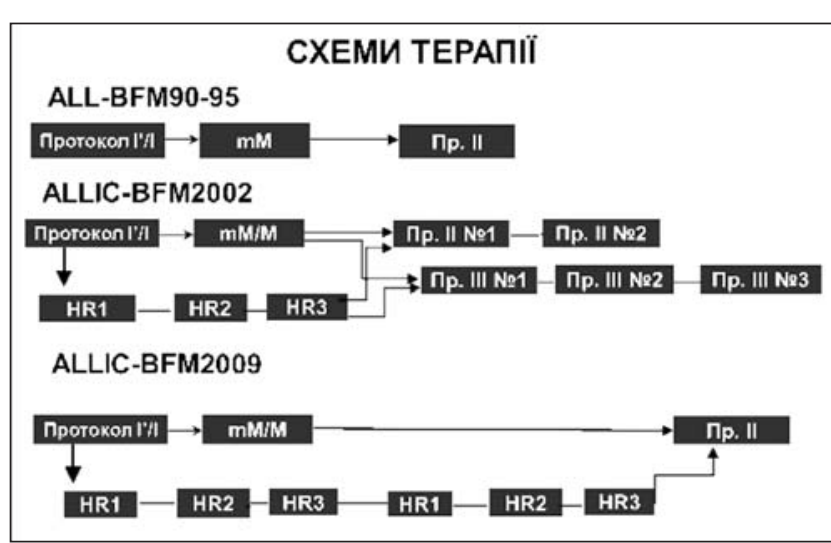

Pис.1. Схематичне зображення інтенсивної фрази протокольної терапії дітей, хворих на ГЛЛ, за стандартними програмами групи BFM

групи середнього ризику (ГСР). До ГНР віднесено дітей віком від 1 року до 6 років з рівнем лейкоцитів менше 20,0 Г/л, абсолютною кількістю бластів на 8-й день преднізолонової префази (PRED) менше 1,0 Г/л та кістково-мозковою ремісією на 33-й день лікування; до ГСР увійшли хворі віком молодше 1 року або старше 6 років з ініціальним лейкоцитозом 20,0 Г/л і більше, бластемією на 8-й день терапії менше 1,0 Г/л та кістково-мозковою ремісією на 33-й день. До ГВР віднесені діти 3 бластемією на 8-й день терапії більше 1,0 Г/л і/або відсутністю кістково-мозкової ремісії на 33-й день I протоколу.

Згодом ДГЛЛУ стала частиною міжнародного дослідження ALLIC-BFM 2002, у якому взяли участь загалом 15 країн світу (130 центрів) [77]. Додатково у стратифікації до певних груп ризику враховувався відсоток бластів кісткового мозку (КМ) на 15-й день. Це терапевтичне дослідження передбачало проведення рандомізації пацієнтів з метою порівняльної оцінки ефективності та токсичності низки нових елементів лікувального протоколу. У протоколі М та блоках HR доза MTX була

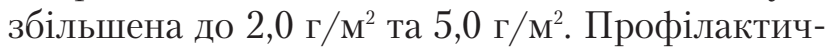
не опроміненя ЦНС (у дозі 12 Грей) отримували тільки пацієнти з Т-ГЛЛ і ГВР віком $\geq 1$ року. Терапевтична краніальна променева терапія була у пацієнтів з ініціальним ураженням ЦНС та призначалася в дозуванні з віком: 12 Гр для дітей віком від 1-го до 2-х років і 18 Гр для дітей віком $\geq 2$ років.

Остання версія протоколу лікування дітей 3 ГЛЛ міжнародної групи BFM - ALLIC-BFM 2009 грунтується на імуноцитологічному визначенні мінімальної залишкової - резидуальної - пухлини - (molecular residual disease (MRD) на 15-й день індукційної терапії із роз- поділом пацієнтів до тієї чи іншої групи ризику. Впровадження такого моніторингу дозволило індивідуалізувати терапію кожного окремого пацієнта із поліпшенням загального результату його лікування [1,77].

Надалі продовжуються клінічні дослідження нових методів лікування групи пацієнтів iз резистентними формами та рецидивами ГЛЛ, які повинні поліпшити прогноз перебігу хвороби. Тому узагальнюючий аналіз застосування модифікованих міжнародних протоколів групи BFM у дітей, хворих на ГЛЛ, впродовж 25 років буде цікавим та корисним для покращення результатів їх лікування.

Mema дослідження: проведення порівняльного аналізу та узагальнення результатів лікування ГЛЛ у дітей за 25 років при застосуванні модифікованих програм цитостатичної терапії міжнародної групи BFM.

\section{Матеріал і методи дослідження}

У 370 дітей віком від 0 до 18 р., хворих на ГЛЛ, проаналізовано результати лікування за стандартами цитостатичної терапії міжнародної групи ВFМ за період з лютого 1993 р. до березня 2018 р.

Діагноз ГЛЛ встановлювався на підставі клінічної картини, лабораторних досліджень: загальний аналіз крові та сечі, цитологічні (підрахунок гемограми та мієлограми, цитозу ліквору, у препаратах, виконаних на цитоспіні, у паноптично забарвлених мазках за МейГрюнвальд-Гімза), біохімічний аналіз крові; проводилися цитохімічні реакції, імунофенотипові дослідження методом проточної цитометрії з використанням моноклональних антитіл (МКАТ). Сукупність поверхневих і цитоплазматичних маркерів у більшості випадків ГЛЛ була підставою для встановлення лінійної належності, виділення стадій зрілості прекурсорів В- чи Т-лімфоцитів. Для оцінки лінійної належності бластних клітин користувалися критеріями діагностики GALGB та EGIL [8, 13-16].

На основі концепції відповідності фенотипу злоякісних клітин виділено низку імунологічних варіантів, що визначають клітинну природу лейкемії і рівень блоку диференціації у неопластичній популяції. Експресією антигена вважали позитивною, коли частка бластів, на поверхні яких знаходився антиген, становила не менше 20,0\% для лімфоїдних та лінійно-незалежних і 30,0\% для мієлоїдних маркерів $[57,83]$. Тому надалі в таблицях і у тексті весь 
аналіз матеріалу, включаючи статистичний, проводився з урахуванням цих меж. Застосовувалися наступні методи візуалізації: рентгенографія органів грудної клітки, ультразвукове дослідження (УЗД), за потреби - комп'ютерна томографія (КТ) та/або магнітно-резонансна томографія (МРТ) голови, органів грудної клітки, черева; пункційна та трепанобіопсія КМ. Проводилося незалежне дослідження препаратів та визначення MRD у Референтній лабораторії НДСКЛ «ОХМАТДИТ» (м. Київ).

Алогенна трансплантація гемопоетичних стовбурових клітин / кісткового мозку (ало-ТГСК /ало-ТКМ) від неродинного донора виконувалася у всіх випадках у закордонних клініках.

Для аналізу застосовано програму статистики Statistica for Windows 8.0 (Statsoft, USA). Функція безподійного виживання - event-free survival (EFS), безрецидивне виживання (disease-free survival (DFS) та загального кумулятивного виживання - overall survival (OS) з першого діагнозу до смерті з будь-якої причини розрахована методом Каплан-Маєра. Порівняння виживання між групами проводилося за допомою Cox's-F-test.

Дослідження виконані відповідно до принципів Гельсінської Декларації. Протокол дослідження ухвалений Локальним етичним комітетом (ЛЕК) установи. На проведення досліджень було отримано поінформовану згоду батьків дітей. (або їх опікунів).

\section{Результати досліджень}

За період з лютого 1993 р. до березня 2018 р. у відділенні гематології та інтенсивної хіміотерапії КЗ ЛОР ЗУСДМЦ проліковано 370 хворих на ГЛЛ віком від 0 до 18 р. (в аналіз не включені пацієнти, які вибули з-під спостереження). Медіана спостереження (МC) за загальною вибіркою хворих становить 118 міс. Хлопчики становлять 54,49\% (209 осіб), дівчатка - 45,51\% (161 дітей), співвідношення 1,3:1. Переважали пацієнти віком від 1 до 6 років - 209 (56,49\%). Наступною за чисельністю була група осіб, старших за 6 та молодших за 12 років - 99 (26,76\%). Пацієнтів старшого віку (після 12 років) нараховано 50 (13,51\%). Дітей до 1 року було 12 (3,24\%).

У 319 (86,22\%) хворих виконано імунофенотипування бластних клітин. За імунофенотиповим варіантом у абсолютної більшості діагностовано В-клітинні ГЛЛ - у 82,13\%
(262 хворих), Т-ГЛЛ - у 46 (14,42\%) осіб, лейкемії з ознаками гібридного або змішаного фенотипу (mixed-phenotype acute leukemia), коли спостерігали одночасно коекспресію на лейкемічних бластах В-, Т-клітинних та мієлоїдних антигенів [28,34,37,42,43,45,50,59,60], у 11 (3,45\%) пацієнтів, причому B+T+Му-ГЛЛ у 7/11 та Т+В+Му-ГЛЛ у 4/11 випадків. Серед В-лінійних переважали діти із фенотипом common (ВІІ)-ГЛЛ - 88,55\% (232 хворих); про-В (ВI) ГЛЛ становили $6,87 \%$ (18 осіб); пре-В (ВIII)-ГЛЛ діагностували лише у $4,58 \%$ (12 дітей). Виявлено експресію тільки В-клітинних антигенів у 194 (74,05\%) дітей. У 59 пацієнтів констатували аберантну експресію одного або двох мієлоїдних антигенів на В-лімфобластах. Лише у $3,44 \%$ пацієнтів (9 випадків) на В-бластах верифіковано асинхронні Т-клітинні маркери. Т-лінійну ГЛЛ без експресії антигенів інших ліній встановлено у 40 (86,96 \%) дітей, у 13,04\% (6 осіб) Т-бласти мали мієлоїдні маркери (табл. 1).

Із лютого 1993 р. до жовтня 2002 р. 143 (38,65\%) пацієнти отримали лікування на основі програм ГЛЛ-ДГЛУ 93/95 (базові протоколи ALL-BFM'90/95) (група 1); з листопада 2002 р. до червня 2012 р. 131 (35,41\%) хворий - ALL IC-BFM 2002 (група 2); із червня 2012 р. 88 (23,78\%) хворих отримали ALL IC-BFM 2009 (група 3). Діти віком до 1 року (8 осіб) із серпня 2008 р. лікувалися за програмами INTERFANT 99/06 (група 4).

Добру відповідь на ініціальну терапію преднізолоном (prednisolon good response (PGR), коли абсолютна кількість бластів на восьмий день протоколу I становила менше 1,0 Г/л, було відзначено у більшості хворих - 306 (82,70\%) осіб. У 64 (17,30\%) дітей число бластів у периферичній крові становило більше 1,0 Г/л (prednisolon poor response (PPR), серед них було 27 (42,19\%) дівчаток та 37 (57,81\%) хлопчиків (табл. 2).

Зазначимо, що первинна відповідь на ініціальну терапію PRED не залежить від статі

\begin{tabular}{|l|c|}
\multicolumn{2}{c}{ Лінійний розподіл Глл } \\
\hline \multicolumn{1}{|c|}{ Лінійний розподіл } & Кількість випадків \\
\hline Тільки В-антигени & 194 \\
В+Т-антигени & 9 \\
В+Му-антигени & 59 \\
В+Т+Му-антигени & 7 \\
\hline Тільки Т-антигени & 40 \\
Т+Му-антигени & 6 \\
Т+В+Му-антигени & 4 \\
\hline Усього & 319 \\
\hline
\end{tabular}


Таблиия 2

Аналіз первинної відповіді на терапію з розподілом хворих за терапевтичним ризиком

\begin{tabular}{|l|c|c|c|c|c|c|c|c|}
\hline \multicolumn{1}{|c|}{ Програма лікування } & $\mathbf{8 - и ̆ ~ д е н ь ~}$ & $\mathbf{1 5 - и ̆ ~ д е н ь ~}$ & $\begin{array}{c}\text { Рання } \\
\text { смерть }\end{array}$ & $\begin{array}{c}\text { 33-й } \\
\text { день }\end{array}$ & 33-й день & ГНР & ГСР & ГВР \\
\hline & $\mathrm{PPR}$ & $\mathrm{NR}$ & & NR & ремісія & & & \\
\hline ГЛЛ-ДГЛЛУ 93/95, n=143 & $18(12,59 \%)$ & - & $7(4,89 \%)$ & $1(0,7 \%)$ & $135(94,4 \%)$ & $25(17,48 \%)$ & $100(69,93 \%)$ & $18(12,59 \%)$ \\
\hline ALL IC-BFM 2002, $\mathrm{n}=131$ & $23(17,56 \%)$ & $25(19,08 \%)$ & $2(1,53 \%)$ & $4(3,05 \%)$ & $125(95,42 \%)$ & $16(12,21 \%)$ & $88(63,21 \%)$ & $27(20,61 \%)$ \\
\hline ALL IC-BFM 2009, n=88 & $18(20,45 \%)$ & $27(30,68 \%)$ & $1(1,14 \%)$ & $2(2,27 \%)$ & $85(96,59 \%)$ & $3(3,41 \%)$ & $56(63,64 \%)$ & $29(32,95 \%)$ \\
\hline Interfant 99/06, $\mathrm{n}=8$ & $5(62,50 \%)$ & - & $1(12,5 \%)$ & 2 & $5(62,5 \%)$ & - & $3(37,5 \%)$ & $5(62,50 \%)$ \\
\hline Усього, $\mathrm{n}=370$ & $64(17,30 \%)$ & - & $11(2,97 \%)$ & $9(2,43 \%)$ & $350(94,59 \%)$ & $44(11,89 \%)$ & $247(66,76 \%)$ & $79(21,35 \%)$ \\
\hline
\end{tabular}

Примітка. *Не враховано 11 дітей, померлих до 33-го дня індукційної терапії.

хворої дитини $(\mathrm{p}>0,05)$. Встановлено, що показник EFS був значно нижчим у дітей із поганою відповіддю на преднізолонову префазу (EFS 56,8\%) порівняно 3 особами, абсолютна кількість бластів у яких на 8-й день лікування становила <1,0 Г/л (EFS 76,9\%) $(\mathrm{p}=0,00001)$.

Аналіз частоти досягнення кістково-мозкової ремісії на 33-й день індукційного лікування свідчить, що цей показник є досить високим $(94,59 \%)$. Не відповідали на індукційну терапію $10(2,7 \%)$ пацієнтів, троє 3 них належали до групи 4. Рання смерть зареєстрована у 11 (2,97\%) пацієнтів від сепсису під час індукційної терапії.

Кумулятивне виживання у всій вибірці становить 78,0\% (рис.2). Загалом померло 73 (18,7\%) дітей. У 32 (43,8\%) осіб смерть пов'язана з терапією I лінії ГЛЛ, 3 них 11 (34,37\%) хворих померли до досягнення ремісії ГЛЛ під час індукційної терапії, 19 (59,37\%) дітей - від септичних ускладнень у ремісії I на різних етапах інтенсивної хіміотерапії, 1 хворий з HR - від посттрансплантаційних ускладнень, 1 хворий - на 160 міс. після досягнення ремісії від фульмінантного перебігу вірусного гепатиту В. У 39 (53,42\%) хворих смерть настала у II гострому періоді від прогресування лейкемії та/або інфекційних ускладнень.

Більшість пацієнтів - $248(67,02 \%)$ - належали до ГСР. Другою за чисельністю була ГВР 77 (20,81\%) осіб. У ГНР налічувалося 45 (12,17\%) хворих. У загальній вибірці показник EFS був достовірно найнижчим у дітей з ГВР порівняно із ГНР та ГСР (56,3\% vs 77,9\% vs $77,9 \%$, $\mathrm{p}=0,00000$ ).

У терапевтичному протоколі ГЛЛ-ДГЛЛУ 93/95 відзначено 18 (12,59\%) пацієнтів PPR, яких віднесено до ГВР. Один з них $(0,7 \%), \mathrm{NR}$, не досягнувши ремісії на 33-й та 52-й день індукційної терапії, продовжив лікування за кордоном, де помер від післятрансплантацій- них ускладнень. У групі 1 найчисельнішою була ГСР - 100 (69,93\%) дітей, а у ГНР налічувалося 25 (17,48\%) осіб.

Серед пацієнтів, яким застосовувалася терапія ALL IC-BFM 2002, до ГВР стратифіковано 27 (20,61\%) осіб. 3-поміж них PPR 23 (85,19\%) дітей, 3 доброю відповіддю на преднізолон, PGR, були 4 (14,81\%) особи, які не досягнули кістково-мозкової ремісії на 15-й день. Число бластів $\geq 5,0 \%$ було у 25 (19,08\%) хворих, незалежно від відповіді на терапію преднізолоном. На 33-й день статус NR відзначено у 4-х (3,05\%) осіб. MRD на 33-й день - у 10 (7,63\%) хворих, зних шестеро досягнули молекулярної ремісії на 52-й день. 4-м пацієнтам з ГВР у I ремісії ГЛЛ проведено ало-ТСГК від неродинного донора, три з яких - успішні. Діти перебувають у довготривалій ремісії. Одна пацієнтка загинула від рецидиву ГЛЛ після ТКМ. 16 (12,21\%) хворих стратифіковані до ГНР, а найбільше осіб віднесені до ГСР 88 (63,18\%) дітей у групі 2.

При проведенні терапії ALL IC-BFM 2009 3 (3,41\%) дітей належали до ГНР та перебувають у клініко-гематологічній ремісії. У ГСР налічувалося 56 (63,64\%) хворих. За терапевтичною відповіддю у ГВР було 29 (32,95\%) осіб.



Рис.2. Кумулятивне виживання, OS 78,0\%, у загальній вибірці хворих на ГЛЛ 




Pис. 3. EFS у дітей до 1 року залежно від застосованого протоколу, Cox's-F-test, $\mathrm{p}=0,11$

Причому У ГBP PPR було 18 та PGR 11 хворих. На 15-й день MDR>10,0\% констатовано у 27 3 них. У 2 (2,27\%) дітей на 33-й день не досягнуто статусу кістково-мозкової ремісії.

У дітей до 1 року, які лікувалися за протоколами INTERFANT 99/06, лише 3 із 8 осіб були PGR, причому у двох з них через 19 та 31 міс. констатовано рецидив ГЛЛ, згодом у II ремісії виконана ало-ТКМ. У одного пацієнта на 129-й день після ало-ТСГК діагностували ЦНС-рецидив хвороби. Один пацієнт перебуває у I ремісії 117 міс. Один 4-місячний хлопчик помер під час індукційної терапії від токсикосептичних ускладнень. У половини хворих до 1-го року з групи 4 exitus letalis - від прогресування ГЛЛ.

Четверо (2,8\%) дітей до 1-го року лікувалися згідно 3 програмою ГЛЛ-ДГЛЛУ 93/95. 3 них один 3-місячний хлопчик з ГВР помер на 3-му місяці індукційного лікування від сепсису. У одного пацієнта з ГСР в 11-місячному віці діагностовано ГЛЛ. Через 37 міс. після досягнення ремісії розвинувся пізній комбінований, кістково-мозковий та ЦНС, рецидив ГЛЛ. Він перебуває у тривалій II клініко-гематологічній ремісії 226 міс. Двоє дівчаток (ГЛЛ діагно- стовано у 9 міс. та 11 міс. з ГВР, PPR) перебувають у ремісії 296 та 271 міс. відповідно. Ми виявили суттєву різницю у EFS - 50,0\% проти 12,5\% у дітей до 1 року, які лікувалися згідно з протоколами ГЛЛ-ДГЛЛУ 93/95 та Interfant 99/06 відповідно. На нашу думку, через малу вибірку пацієнтів не знайдено статистичної різниці між цими групами $(\mathrm{p}=0,11)$ (рис.3).

У результаті проведеного лікування станом на 1 березня 2018 р. у клініко-гематологічній ремісії перебували 317 (85,68\%) дітей. 3 них 215 (67,82\%) хворих спостерігалися понад 5 років, і у них не було зареєстровано подій (рецидиву, резистентності до терапії, смерті, вторинні пухлини). За час дослідження події виникли у 90 (24,32\%) хворих. Абсолютна більшість подій $(92,22 \%$ - 83 особи) ставалися

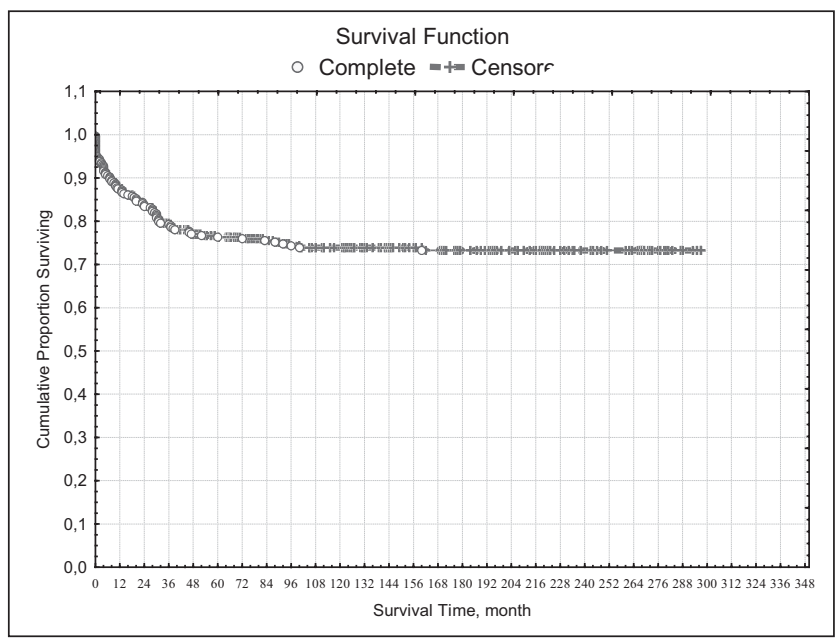

Pис.4. EFS 73,2\% у загальній вибірці хворих на ГЛЛ

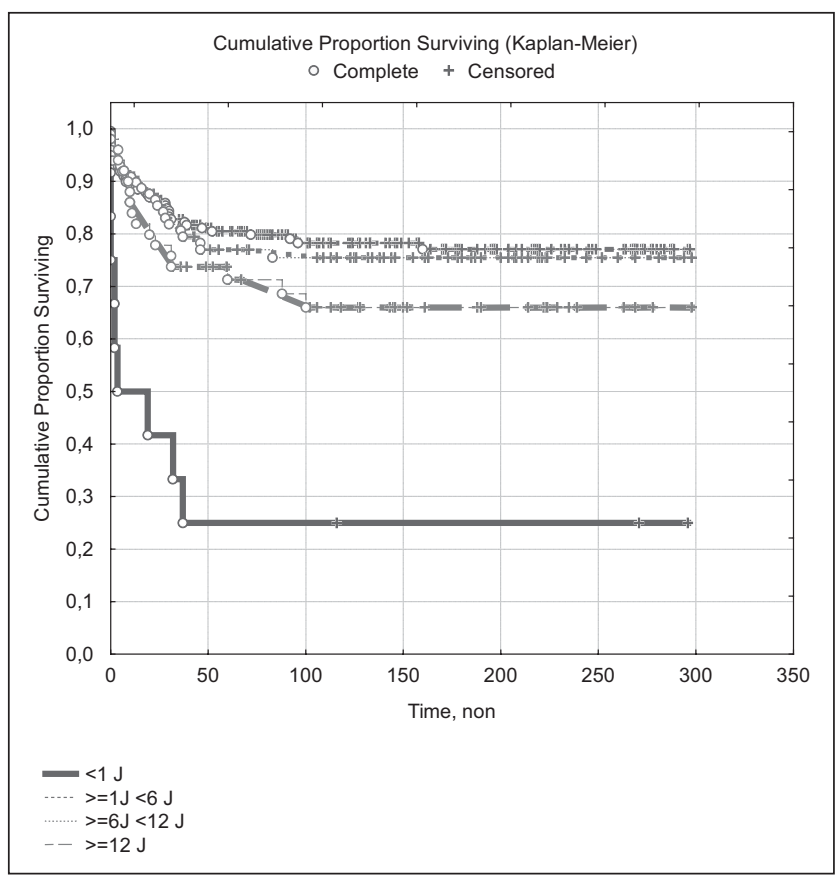

Pис.5. EFS залежно від віку, Cox's-F-test, $\mathrm{p}=0,00004$ 


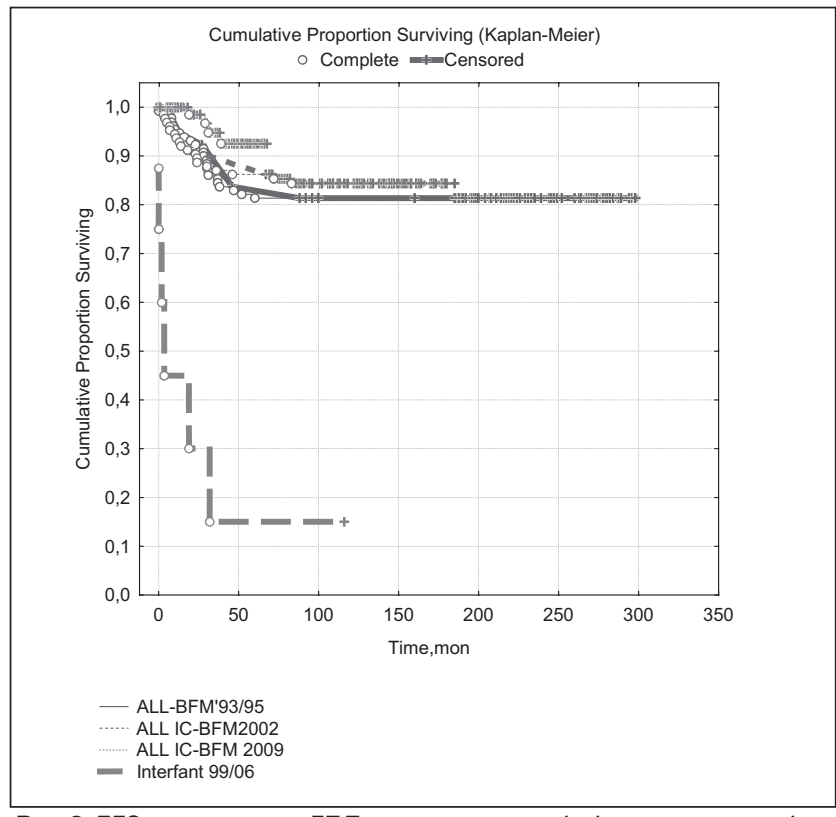

Pис.6. EFS у хворих на ГЛЛ при проведенні різних протоколів групи BFM, Cox's-F-test, $p=0,00000$

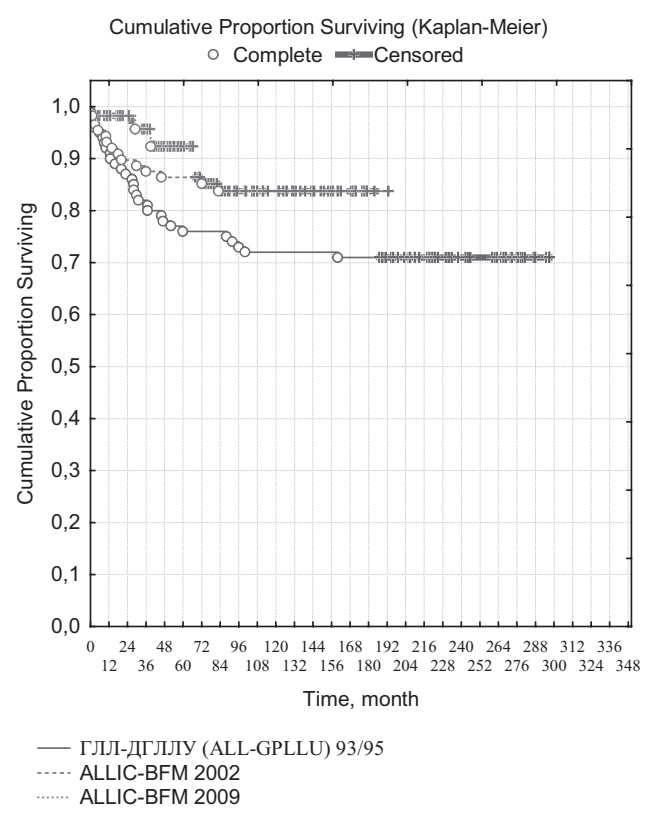

Pис.7. EFS у хворих на ГЛЛ у групі середнього ризику при проведенні різних протоколів групи BFM, Cox's-F-test, $\mathrm{p}=0,04232$

не пізніше 60 місяця з початку спостереження. Частка EFS за весь період спостереження становить 73,2\% (рис.4).

Статистично встановлено, що показник EFS був вищим у дівчат порівняно з хлопчиками (80,0\% проти 67,8\%, p=0,021). Вірогідно гірші терапевтичні результати спостерігали у дітей віком до 1 року (25,0\%) ( $\mathrm{p}=0,00004)$ (рис. 5).

Значно коротшою була тривалість EFS у дітей, які отримали лікування Interfant 99/06 (12,5\%), ніж при застосуванні інших протоко-



Pис.8. EFS хворих на ГЛЛ у групі високого ризику при проведенні різних протоколів групи BFM, Cox's-F-test, $p=0,09653$

лів ГЛЛ ( $\mathrm{p}=0,00000)$ (рис.6). Результати лікування були значно кращими у дітей, які отримали терапію за програмою ALL IC-BFM 2009, порівняно $з$ дітьми групи 1 (85,2\% проти $68,3 \%$, $\mathrm{p}=0,0253)$. Встановлено, що не було відмінностей у EFS між групами 1 та $2(\mathrm{p}=0,19)$, також показник EFS вірогідно не відрізнявся між групами 2 та $3(\mathrm{p}=0,14)$.

У загальній вибірці доведено, що діти 3 ГВР мали значно менший відсоток EFS (56,3\%) порівняно з хворими, які належали до ГНР (77,9\%) та ГСР (74,9\%), $\mathrm{p}=0,00000$.

Порівняльний аналіз у ГСР продемонстрував, що терапія була ефективнішою при проведенні програми ALL IC-BFM 2009, ніж у дітей 3 групи ГЛЛ-ДГЛЛУ 93/95 (EFS 90,6\% vs $71,0 \%, \mathrm{p}=0,03125)$. Таку ж тенденцію виявлено між групами 1 та 2 для дітей, які належали до ГСР (71,0\% vs 83,7\%, p=0,066) (рис.7). Не знайдено достовірної різниці у EFS між пацієнтами з ГСР, які отримали програмне лікування ALL IC-BFM 2002 та ALL IC-BFM $2009(\mathrm{p}=0,24312)$.

Схожі результати виявлено у пацієнтів з ГВР, які належали до вищезгаданих терапевтичних курсів (група $1-50,0 \%$ vs група $3-$ $73,9 \%, p=0,04560$ ) (рис. 8). Показник EFS у ГНР не мав зв'язку із застосованим терапевтичним протоколом (група $1-72,0 \%$ vs група $2-$ $81,3 \%$ vs група $3-100,0 \%)$. 


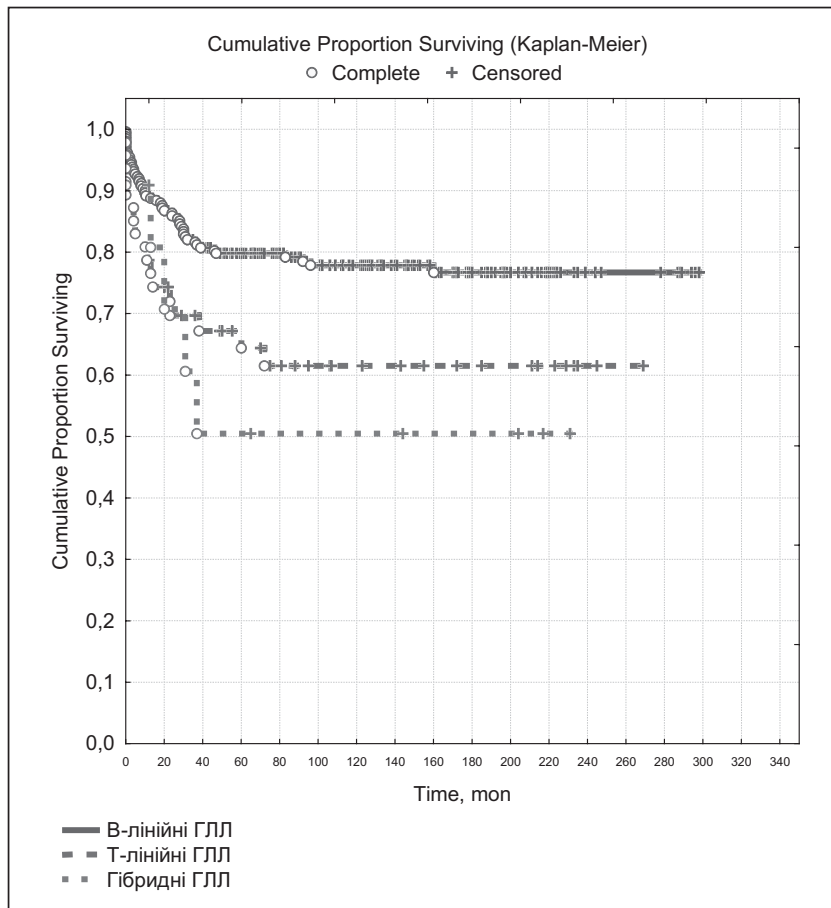

Pис. 9. EFS залежно від імунофенотипового варіанту ГЛЛ, Cox's-F-test, $p=0,00102$

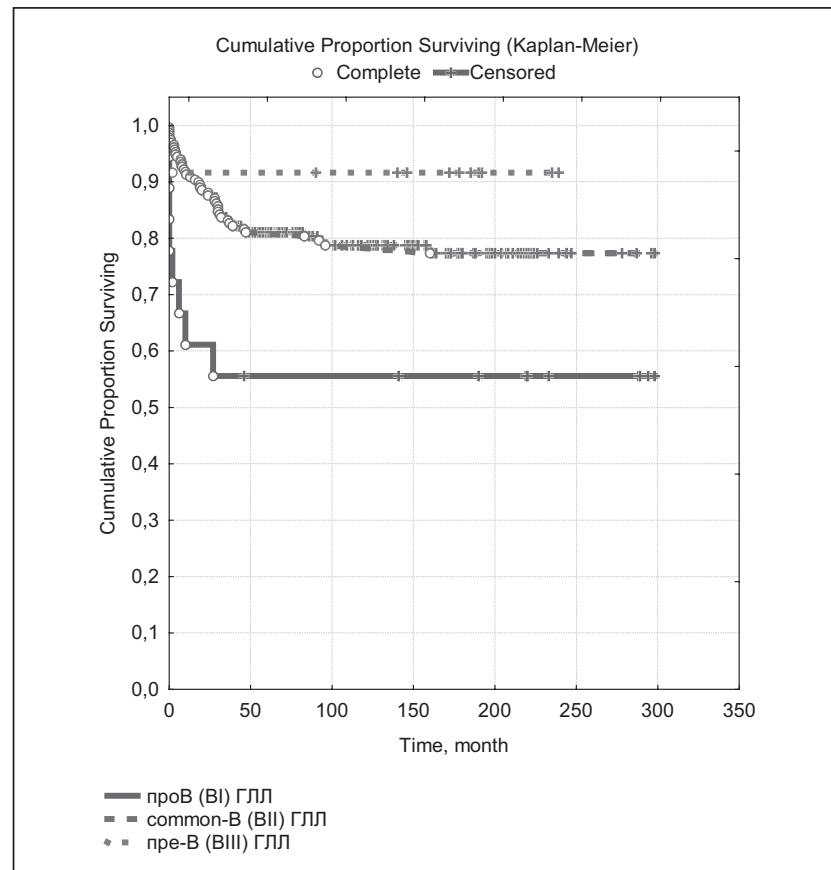

Pис.10. EFS у дітей 3 з різними варіантами В-лінійної ГЛЛ, Cox's-F-test, $p=0,00449$

Встановлено, що EFS у дітей із гібридним імунофенотипом був найнижчим $-50,6 \%$, найкращим у всій вибірці В-лінійних ГЛЛ $-76,6 \%$, а у осіб із Т-ГЛЛ - 60,7\% (p=0,00102) (рис. 9).

Результати лікування були вірогідно кращими у пацієнтів з пре-В ГЛЛ та common-В-ГЛЛ, ніж із про-В-лейкеміями ( $\mathrm{p}=0,00449)$ (рис. 10). Коекспресія мієлоїдних чи Т-лінійних маркерів у хворих на лейкемії з імунофенотипом

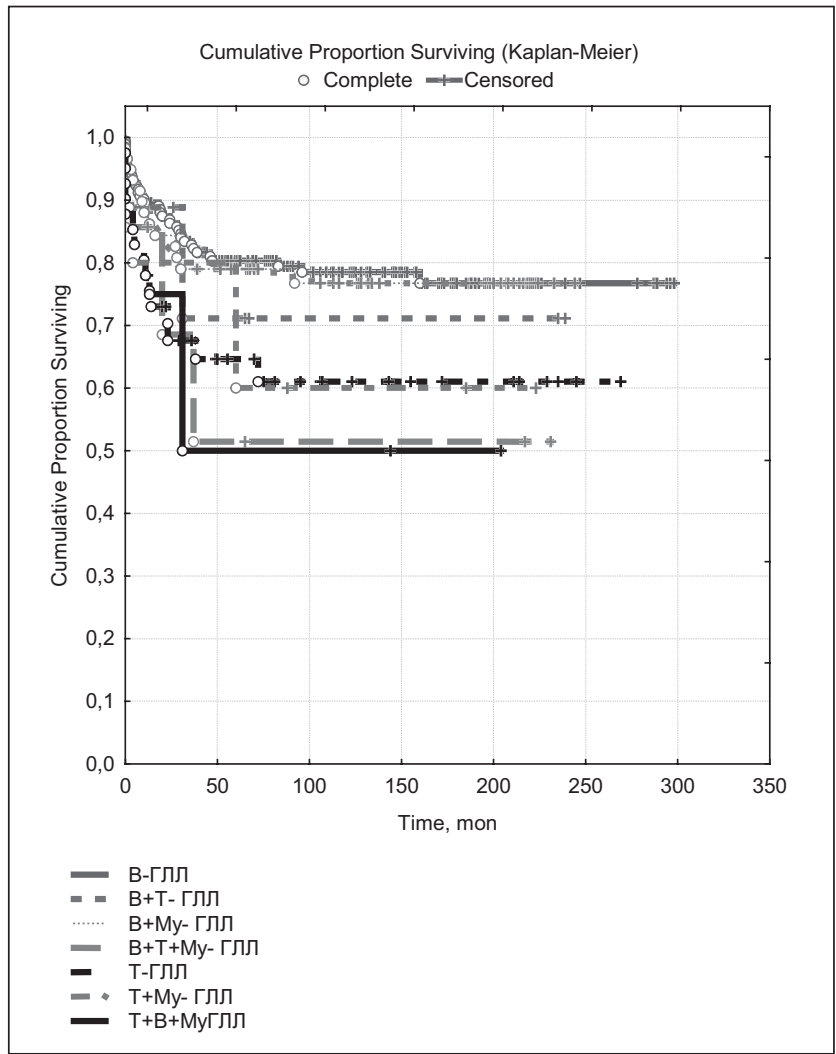

Pис.11. EFS залежно від імунофенотипового підваріанту ГЛЛ, Cox's-F-test, $p=0,18533$

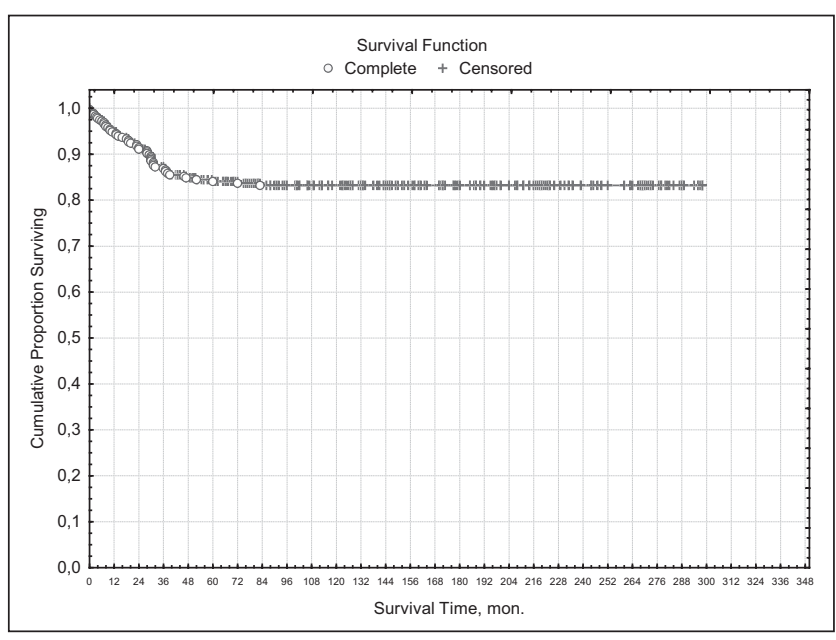

Pис.12. DFS 83,2\% у загальній вибірці хворих на ГЛЛ

B-лінії не мала впливу на EFS («чисті» В-лінійні ГЛЛ - 76,6\% vs В+Му-ГЛЛ - 76,8\% vs В+Т-ГЛЛ - 73,3\%, p=0,90810). Не знайдено значущого зв'язку між показником EFS у дітей 3 Т-лінійною ГЛЛ та Т+Му-ГЛЛ (58,9\% vs $64,8 \%, \mathrm{p}=0,60456$ ) (рис. 11).

Достовірно встановлено, що хворим на про-В ГЛЛ притаманне високе число смертей (OS про-В-ГЛЛ - 55,6\% vs common-В-ГЛЛ 80,4\% vs пре-В-ГЛЛ - 91,7\%) порівняно з дітьми, яким діагностовано інші імунофенотипові підваріанти ГЛЛ ( $\mathrm{p}=0,00068)$. Доведено, що 
Аналіз рецидивів гострої лімфобластної лейкемії

\begin{tabular}{|l|c|c|c|c|c|}
\hline \multicolumn{1}{|c|}{ Рецидив } & $\begin{array}{c}\text { Кістково- } \\
\text { мозковий }\end{array}$ & Нейрорецидив & Тестикулярний & $\begin{array}{c}\text { Комбінований кістково-мозковий } \\
\text { + нейрорецидив }\end{array}$ & Усього \\
\hline Дуже ранній & 12 & - & - & 8 & $20(37,74 \%)$ \\
\hline Ранній & 7 & 3 & - & - & $10(18,86 \%)$ \\
\hline Пізній & 16 & 1 & 3 & 3 & $23(43,40 \%)$ \\
\hline Усього & $35(66,04 \%)$ & $4(7,55 \%)$ & $3(5,66 \%)$ & $11(20,75 \%)$ & $53(100,00 \%)$ \\
\hline
\end{tabular}

наявність змішаного фенотипу ГЛЛ супроводжується більшою частотою летальних наслідків (В-лінійні ГЛЛ - 79,6\% vs Т-ГЛЛ - 66,3\% vs ГЛЛ із одночасною коекспресію на лейкемічних бластах В-, Т-клітинних та мієлоїдних антигенів $-61,9 \%, \mathrm{p}=0,00916)$. Щодо розвитку рецидиву між окремими варіантами В-лінійної ГЛЛ не виявлено достовірної різниці ( $\mathrm{p}=0,21009)$. Не знайдено зв'язку із настанням рецидиву та наявністю на лімфобластах інших додаткових маркерів ( $\mathrm{p}=0,38370)$.

Незважаючи на те, що ГЛЛ добре реагує на хіміотерапію, рецидив залишається основною проблемою. У 53 (16,21\% з 327 хворих з вилученням 11 NR та 32 померлих) виникли рецидиви хвороби. 3 них у 6 (75,0\%) пацієнтів зареєстровано рецидиви хвороби у групі 4 (iз 8 дітей), у 4 (4,55\%) випадках - 388 осіб,

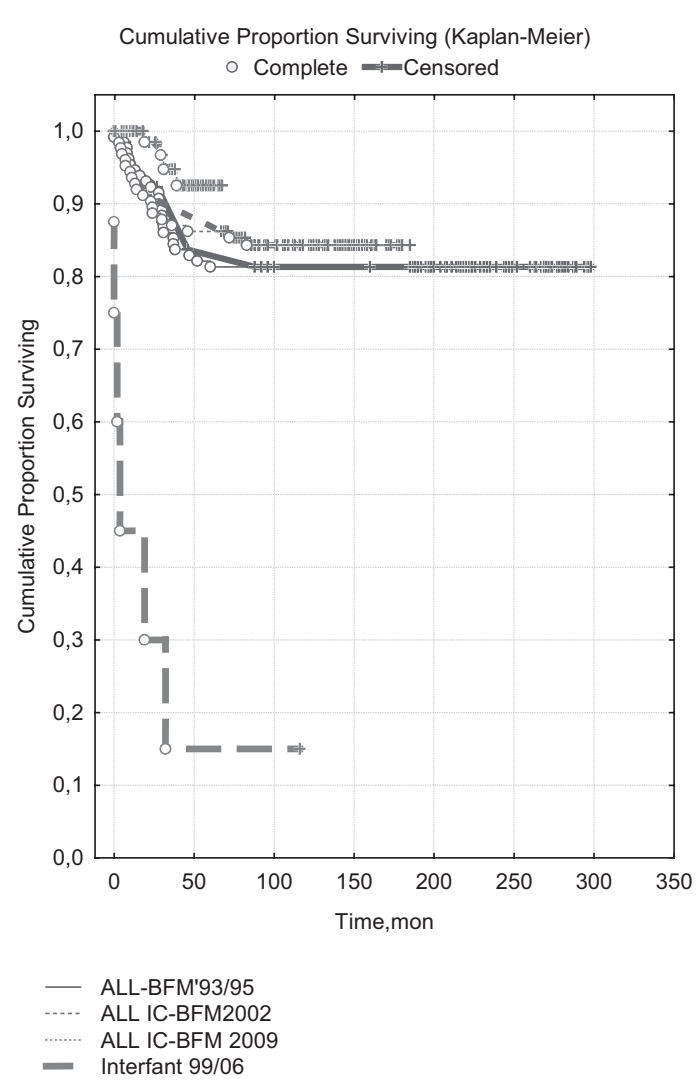

Pис.13. DFS при проведенні різних стандартних протоколів групи BFM, Cox's-F-test, $p=0,00000$ які лікувалися за програмою ALL IC-BFM 2009, у 19 (14,50\%) пацієнтів 3-поміж 131 пацієнта 3 терапевтичної програми ALL IC-BFM 2002 та 24 (16,78\%) із 143 дітей групи 1. Безрецидивне виживання у загальній вибірці становить $83,2 \%$ (рис. 12 ).

Рецидив ГЛЛ діагностовано у 36 (17,22\%) хлопчиків та у 17 (10,56\%) дівчаток. Виявлено тенденцію до зниження показника DFS у хлопчиків порівняно з дівчатками (80,0\% vs 88,1\%, $\mathrm{p}=0,07018)$. За терміном реєстрації рецидиви були дуже ранніми (виникали до 18 міс. з часу початку первинної терапії ГЛЛ) у 20 (37,74\%) осіб та ранніми (у терміні 18-30 міс. від початку первинної терапії лейкемії) у 10 (18,86\%) випадках. Пізні рецидиви ГЛЛ (після 30 міс. від дебюту терапії І гострого періоду) зафіксовано у 23 (43,40\%) дітей. Дані щодо локалізації рецидивів відображено у табл. 3.

Доведено, що у загальній вибірці DFS було найнижчим у ГВР порівняно з ГНР та ГСР ( $85,2 \%$ vs $85,8 \%$ vs $74,8 \%, p=0,00726)$. Встановлено, що показник DFS достовірно найгірший у пацієнтів, які лікувалися за терапевтичним протоколом Interfant 99/06 (15,0\%), та найкращий у пацієнтів, які лікувалися згідно з програмою ALL IC-BFM 2009 (92,0\%), у групах 2 та $3-82,0 \%$ та $84,5 \%$ відповідно $(\mathrm{p}=0,00000)$ (рис.13).

Рідкісним віддаленим наслідком лікування ГЛЛ у дітей були вторинні злоякісні захворювання, які зареєстровано у 5 (1,35\%) дітей (рис. 14). Медіана віку на час діагностики ГЛЛ чотири роки. Медіана виявлення вторинних пухлин $з$ часу початку первинної цитостатичної терапії -7 років 4 міс. (коливання 20-96 міс.). У 3/5 пацієнтів діагностовано вторинні пухлини головного мозку (ВПГМ). Середній вік на момент постановки первинного діагнозу ГЛЛ у цих осіб становив 7,4 року, вік на момент виникнення ВПГМ - 21 р. 7 міс., 11 р., 9 р. 4 міс. відповідно. Саме ці три пацієнти отримували лікування за модифікованою програмою поліхіміотерапії ГЛЛ-ДГЛЛУ 95 (на основі програми ALL-BFM'95). За резуль- 


\begin{tabular}{|c|}
\hline $\begin{array}{c}\text { Вторинні пухлини, після терапії І-го } \\
\text { гострого періоду ГЛЛ } \\
\text { у } 5(1,3 \%) \text { дітей виникли вторинні пухлини: }\end{array}$ \\
\hline $\begin{array}{l}\text { BFM 90-95 } \\
\text { - Олігодендрогліома (померла) } \\
\text { - Астроцитома (оперована, хіміотерапія, } \\
\text { променева терапія, живе, народила доньку) } \\
\text { - Доброякісна менінгеома (оперований, живе) }\end{array}$ \\
\hline $\begin{array}{l}\text { ALLIC-BFM } 2002 \\
\text { - Вторинна ГМЛ (живе після ТКМ) АГРЕСИВНА } \\
\text { - Вторинний МДС/ГМЛ (помер) }\end{array}$ \\
\hline $\begin{array}{l}\text { Медіана віку діагнозу ГлЛ - } 4 \text { роки, } \\
\text { Медіана виникнення вторинних пухлин від часу } \\
\text { захворювання - } 7 \text { р. } 4 \text { міс. (20-96 міс) }\end{array}$ \\
\hline
\end{tabular}

Рис. 14. Аналіз вторинних пухлин у пацієнтів, які отримали терапію за стандартними протоколами, групи BFM у дитячому віці з приводу ГЛЛ

татами первинної відповіді на індукційне лікування (добра відповідь на преднізолонову префазу, досягнуто клініко-гематологічної ремісії на 33-й день) усі згадані діти віднесені до терапевтичної групи ГСР. Одна пацієнтка 3 олігодендрогліомою померла від прогресування вторинної неоплазії. Двоє осіб з фібринозною астроцитомою та менінгіомою живуть. У жодного хворого з інших груп - 2, 3 чи $4-$ не зареєстровано ВПГМ.

У двох хлопців, які отримували терапію за програмою ALL IC-BFM-2002 (відповідно належності до терапевтичних груп ГСР та ГВР) зареєстровано через 20 міс. з часу початку первинної цитостатичної терапії вторинний гемобластоз (treatment-related myelodysplastic syndrome (t-MDS)/ treatment-related acute myeloid leukemia (AML) - t-MDS/t-AML). У одного пацієнта з ГСР виник вторинний мієлодисплатичний синдром (МДС) із моносомією 7, який згодом трансформувався у вторинну ГМЛ, хворому проведено алогенну трансплантацію гемопоетичних клітин (алоТГПСК) пуповинної крові. Пацієнт помер від посттрансплантаційних ускладнень. У іншого хворого із ГВР зареєстровано вторинну ГМЛ з транслокацією t(9.11) (p22; q23). Йому виконано ало-ТСГК. Пацієнт перебуває у клініко-гематологічній ремісії ГЛЛ 78 міс. та t-AML - 50 міс.

Ало-ТГСК виконано загалом 15-м особам. 3 них у I ремісії ГЛЛ у ГВР 8 осіб, включно з двома пацієнтами із вторинною t-MDS/t-AML, та 7 особу II ремісії ГЛЛ.

\section{Обговорення}

Лейкемії, з яких понад 95,0\% є гострими, є найпоширенішою діагностичною групою дитячих онкологічних захворювань в усьому світі [51,78]. Досягнуто відчутного прогресу у лікуванні ГЛЛ, відзначеного 5-річним загальним виживанням, що сягає 90,0\%, як і у країнах з високим рівнем доходів [65]. Запровадження міжнародних протоколів поліхіміотерапії ГЛЛ групи BFM у відділенні гематології та інтенсивної хіміотерапії ЗУСДМЦ зумовило суттєве покращання результатів лікування дітей, що й засвідчує наше дослідження. Вважаємо, що показник загального кумулятивного виживання 78,0\%, EFS 72,3\% та безрецидивного виживання 83,2\% впродовж 25 років спостереження у нашому Центрі є великим успіхом в онкогематології Європи та України зокрема. Досягнуті показники виживання відповідають результатам провідних світових центрів [65].

Нами виконано імунофенотипування бластних клітин у 319 осіб. Панель МКАТ включала специфічні антитіла до різних кластерів диференціації (CD): лінійно-незалежні, В-лінійні, Т-лінійні, а також окремі мієлоїдні. Досить цікавим явищем є коекспресія, тобто наявність на морфологічно фенотипово встановлених клітинах гострих лейкемій детермінант 3 іншої лінії, т. 3. «нетипових фенотипів» - «atypical phenotypes» [62]. Зустрічаються випадки гострого лейкозу зі змішаним фенотипом (mixed phenotype acute leukemia (MPAL), відомого ще як гостра біфенотипова або гібридна лейкемія), що є діагностичною та терапевтичною дилемою. MPAL становлять 3,0-5,0\% усіх випадків гострого лейкозу [70], що засвідчило наше дослідження. Ми встановили змішано-лінійну лейкемію у 11 (3,45\%) пацієнтів, причому B+T+Му-ГЛЛ - у 7/11 та Т+B+My-ГЛЛ - у 4/11 випадків. За даними низки авторів, у 5,0-10,0\% хворих спостерігаються такі форми лейкемії, при яких бластні клітини на поверхневій мембрані містять більше двох лімфоїдних та мієлоїдних маркерів, або лейкемія одночасно є трилінійного походження [28,42,50].

Гостра лейкемія змішаного фенотипу це рідкісний тип лейкемії, який експресує як мієлоїдні, так і лімфоїдні маркери. Існує обмежена інформація, особливо щодо дітей, про ці варіанти лейкемій [59]. Система оцінки за європейською групою з імунологічної класифікації лейкемій (EGIL) однозначно визначає 1ї як лейкемію, що має аберантні маркери різних ліній гемопоезу. Класифікація лейкемій (EGIL) визначає гостру лейкемію змішаного 
фенотипу та описує три іiї форми: гостра лейкемія з двома різними лейкозними популяціями, кожна з яких належить до іншої лінії [87], гостра лейкемія з раннім переходом від одного походження до іншого [12,36] і гостра лейкемія з виразними аберантними молекулами (ті, які фізіологічно виражені в різних лініях) [35,60]. На думку E.G. Weir (2001), змішано-лінійні (гібридні) лейкемії є не що інше, як хронічна мієлоїдна лейкемія (ХМЛ) у змішаній лімфобластно-мієлоїдній кризі з виключно поганим прогнозом [88]. Ряд авторів вважають, що аберрантні молекули часто проявляються в подальшому лейкемічними рецидивами [43,48]. Діагностування таких фенотипів бластів у часі ремісії є основою для виявлення бластних клітин поміж фізіологічних елементів кісткового мозку для визначення залишкової хвороби, MRD [1,17,41,48-50,59,65,66,71,77,79,84,90], моніторинг якої успішно проводився у педіатричних пацієнтів України із ГЛЛ у Референтній лабораторії НДСКЛ «ОХМАТДИТ» (м. Київ). M. Khan та співавт. відзначають, що змішано-лінійні ГЛЛ мають значно гірший прогноз [34]. Подібні результати зі статистично меншим виживанням 53,0\% для лейкемій зі змішаним фенотипом проти 76,0\% у дітей 3 фенотипово «чистим» варіантом ГЛЛ подають Е. Mejstrikova та співавт. (2010) [49]. У нашому дослідженні діти з гібридними формами лейкемії мали достовірно коротше EFS $(50,6 \%)$, ніж особи з В-лінійною та Т-ГЛЛ (EFS 76,6\% та 60,7\% відповідно, p=0,018).

Ми підтвердили результати низки дослідників, що серед ГЛЛ переважають діти з фенотипом common (BII)-ГЛЛ - 88,55\% [3-5,8,88]. У 59 пацієнтів констатували аберантну експресію одного або двох мієлоїдних антигенів на В-лімфобластах. Лише у 3,44\% пацієнтів (9 випадків) на В-бластах верифіковано асинхронні Т-клітинні маркери. Т-лінійну ГЛЛ без експресії антигенів інших ліній встановлено у 40 (86,96\%) дітей, та у 13,04\% (6 осіб) Т-бласти мали мієлоїдні маркери. Слід зазначити, що у літературі з цього питання є значні розбіжності. Деякі автори подають значно вищі показники частоти аберантних експресій маркерів інших ліній при В-лінійних ГЛЛ. У дослідженні С.Н. Риі та співавт. (1998) у 31,4\% хворих на ГЛЛ спостерігали один або більше мієлоїдних антигенів, серед В-лінійних ГЛЛ - у 31,9\% хворих та у 28,8\% випадках Т-клітинної лейкемії [66].
Клінічне значення коекспресії маркерів на лімфобластах у дітей широко досліджується і має контраверсійний характер. Різні студії демонструють Му+ГЛЛ дітей як осіб із поганими результатами лікування [22,37,89]. Протилежні дані описують інші дослідники [64,67,68,83]. M.K. Howard та співавт. (1994) вважають, що різниця у результатах терапії може бути пов'язана із різними критеріями визначення Му+-маркерів та застосуванням різних протоколів лікування [29]. Дослідження H. Firat та співавт. (2001) продемонстрували, що визначення CD13 та CD33 залежить від визначального МКАТ і має коливання імунореактивності при дитячих ГЛЛ [23]. Австрійська група дослідників встановила, що діти $3 \mathrm{My}+$ ГЛЛ мають значно менше виживання [22]. Вони спостерігали у хворих на ГЛЛ з кМу значно вищий ініціальний лейкоцитоз, ніж у дітей, на лімфобластах яких не виявлялась коекспресія Му-маркерів. На думку авторів, більше 40,0\% хворих на Му+ГЛЛ припадає на CD10- про-В ГЛЛ [22]. Вважається, що ці хворі на ГЛЛ мають найгірший прогноз з-поміж всієї групи дітей із кМу. Подібні дані подають S. Wiersma та співавт. (1991) [89]. На противагу до них інші дослідники не знаходять статистичної різниці у виживанні між особами із додатньою коекспресією Му-маркерів та мієлонегативними випадками ГЛЛ, хоча EFS у Мy+ хворих є дещо коротшим [45,64]. Кардинально протилежною $є$ думка російських вчених, що наявність мієлоасоційованих антигенів у дітей, хворих на В-лінійну ГЛЛ, є сприятливим прогностичним фактором [4]. Подібно до них Г.В. Коленкова і співавт. (1997) описали, що випадки ГЛЛ без експресії стовбурового антигена та мієлоїдних антигенів виявились схильними до виникнення дуже ранніх та ранніх рецидивів [3]. У дослідженнях малайзійської популяції групи Му+В ГЛЛ та Му-В ГЛЛ не відрізнялися за демографічними та клінічними характеристиками [57]. Нами теж не знайдено суттєвої різниці у виживанні пацієнтів мієлонегативних та позитивних В- та Т-лінійних ГЛЛ.

Більшість дослідників вважають, що фактором несприятливого прогнозу при дитячій В-лініний та Т-клітинній ГЛЛ є погана первинна відповідь на преднізолонову префазу [2,18,19,25,26,31,68,69]. У дослідженні ALL-BFM 83, яка вперше ввела прогностичний фактор відповідь на преднізолонову префазу, 13-річ- 
ний EFS у групі PGR та PPR становили відповідно 65,0\% проти 39,0\% [76]. Добру відповідь на ініціальну терапію преднізолоном нами відзначено у переважної кількості хворих $306(82,70 \%)$ осіб. Встановлено, що показник EFS був значно нижчим у дітей із поганою відповіддю на преднізолонову префазу (EFS 56,8\%) порівняно з особами, абсолютна кількість бластів у яких на 8-й день лікування становила $<1,0$ Г/л (EFS 76,9\%) ( що відповідає даним низки досліджень [2,18,19,25,26, 31,68,69]. Покращання терапевтичних результатів у дітей із поганою відповіддю на лікування студії BFM вдалося досягти завдяки інтенсифікації хіміотерапії. У порівняльному аналізі досліджень групи ВFM демонструється суттєве покращання результатів лікування, пов'язане 3 інтенсифікацією терапії наростанням дози МТХ, що й підтверджує наше дослідження [74,76]. Аналіз частоти досягнення кістково-мозкової ремісії на 33-й день індукційного лікування показав, що цей показник є досить високим (94,59\%), що співзвучне із низкою наукових світових досліджень [5,68,75]. Діти до одного року демонструють найгірші рельтати лікування $[19,20,61]$, що також підтвердило наше дослідження.

Рецидив ГЛЛ може виникнути в різні терміни від початку первинного лікування та вразити будь-який орган [21,32,56,80,81]. F. Bessho та співавт. (2013) описали розвиток рецидиву ГЛЛ аж через 34 роки з часу первинного діагнозу [9]. За даними літератури, найчастішим рецидивом є кістково-мозковий, який становить близько 50,0-97,0\% усіх рецидивів [51]. На ЦНС рецидив припадає в середньому у 8,0-15,0\% випадків [32,38,51]. Існують повідомлення про сукупний ризик рецидиву ЦНС 0,9-4,0\% інших сучасних клінічних випробувань [63]. За п'ять років спостереження у студіях ALL-BFM 90 та ALL-BFM 95 зареєстровано ЦНС-рецидивів 2,9\% та 4,6\% відповідно, а рецидивів іншої локалізації - 15,9\% та 9,9\% відповідно. Близько 20,0\% усіх рецидивів припадає на ураження яєчок $[1,80,81]$. У нашому дослідженні рецидиви (разом із комбінованими) у ЦНС становили 15 (28,3\%), ізольований ЦНС $-7,55 \%$, у кістковий мозок $-46(86,8 \%)$ та тестикулярний $-3(5,66 \%)$ випадків усіх рецидивів.

Зі зниженням ризику рецидиву лейкемії цитостатичне лікування має ряд пізніх побічних впливів, які можуть розвинутись згодом.
Одним з пізніх ускладнень лікування є виникнення вторинних пухлинних захворювань $[24,27,58,70,73,86]$. Часовий діапазон виникнення вторинних неоплазій (BН) після застосування цитостатичної терапії коливається від 0,9 до 20 років і більше [10,44]. Встановлено, що у осіб, які отримували протипухлинну терапію в дитинстві, у 7 [54] та 14 [44] разів вищий ризик щодо розвитку згодом другої злоякісної пухлини порівняно із загальнопопуляційною когортою. Серед ВН, що спостерігаються після лікування ГЛЛ, найчастіше реєструються пухлини ЦНС у хворих, які отримують краніальне опромінення [6,11]. Також у цій популяції хворих можливі вторинні лімфоми ГМЛ, МДС та рак щитоподібної залози [44]. Низка вчених стверджують, що вік пацієнта на час встановлення першого діагнозу і початку протипухлинного лікування має вагомий вплив на ризик розвитку пухлин головного мозку [44,56]. Існують наукові твердження, що у дітей із вперше діагностованою ГЛЛ у віці до 5 років із вторинних неопроцесів найчастіше згодом розвиваються ВПГМ, другою за частотою є МЛ. Усі інші види злоякісних процесів сукупно є третьою найчастішою групою [55]. Нами діагностовано вторинні злоякісні захворювання у 5 (1,35\%) дітей, які отримували терапію з приводу ГЛЛ. Медіана віку на час діагностування ГЛЛ у них становила 4 роки. Медіана виявлення вторинних пухлин з часу початку первинної цитостатичної терапії 7 років 4 міс. (коливання 20-96 міс.). У 3/5 пацієнтів діагностовано вторинні пухлини головного мозку, у 2/5 - гемобластози ГМЛ та МДС, який згодом транформувася у ГМЛ, що відповідає даним вищезгаданих публікацій.

Враховуючи вищезазначене, ми вважаємо, що коригування терапії згідно з результатами визначення MRD, дають змогу індувідуально підходити до кожного пацієнта, застосовуючи більш інтенсивні методи лікування за необхідності, a y групах з меншим показником MRD зменшуючи побічні токсичні ефекти для поліпшення виживання дітей з гострим лейкозом в Україні.

\section{Висновки}

Програми лікування ГЛЛ міжнародної групи BFM демонструють постійно зростаючу високу ефективність. Коекспресія мієлоїдних чи Т-лінійних маркерів у хворих на лейкемії із імунофенотипом В-лінії, мієлоїдних антигенів на Т-бластах не має впливу на EFS. Доведе- 
но, що наявність гібридного та про-В-фенотипу ГЛЛ супроводжується гіршим EFS за рахунок більшої частоти летальних наслідків. Протокол ALL IC-BFM 2009 демонструє найкращу ефективність лікування не-В-гострої лімфобластної лейкемії у дітей. Коректна стратифікація хворих на групи ризику є вкрай важливою для забезпечення оптимального терапевтичного результату (максимум ефективності, мінімум токсичності). Лікування хворих високої групи ризику потре- бує подальшого пошуку шляхів як підвищення ефективності терапії, так і зниження її токсичних ефектів. Результати лікування ГЛЛ у дітей першого року життя є незадовільними та потребують удосконалення терапевтичних підходів. Рідкісним віддаленим наслідком лікування ГЛЛ у дітей є ВН, про що повинні пам'ятати лікарі першого контакту та вузькі спеціалісти.

Автори заявляють про відсутність конфлікту інтересів.

\section{ЛITЕРАТУРА}

1. Донська СБ. (2012). Результати лікування гострої лімфобластно лейкемії у дітей в Україні. Здоров'я України. http://healthua.com/pics/pdf/ZU_2012_Onko_5-6/30-31.pdf.

2. Дудкин СА, Чуниховский С̆, Стренева ОВ и др. (2003). Промежуточный анализ мультицентрового исследования ALL-MB 91 и ALL-BFM 90: результаты терапии детей с инициальным гиперлейкоцитозом и Т-клеточным вариантом ОлЛ. Актуальные проблемы гематологии и трансфузиологии: V съезд гематологов и трансфузиологов Республики Беларусь. Минск: Стринко: 204-205.

3. Коленкова ГВ. (2002). Маркеры острого лейкоза в диагностике и прогнозе заболевания у детей. Гематология и трансфузиология. 47(2): $28-35$.

4. Ленская РВ, Коленкова ГВ, Тимаков АТ. (2000). Клиническое значение характера экспрессии CD-антигенов бластных клеток при остром лимфобластном лейкозе у детей. Экспериментальная онкология. 22(4): 191-194.

5. Armata J, Boguslawska-Jaworska D, Kolecki P, Kowalszyk J, Ochocka M, Radwanska U, Sonta-Jakimczyk D, Wachowiak J. (1998). Bialaczki u dzieci. Pod redakcja U. Radwalskiej. Wrocnaw (Poland): Volumed: 234.

6. Aung L, Khyne T, Yeoh AE, Quah TC, Tan AM. (2009). A report from the Singapore Childhood Cancer Survivor Study (SG-CCSS): a multi-institutional collaborative study on long-term survivors of childhood cancer, initial analysis reporting for the SG-CCSS. Ann Acad Med Singapore. 38(8): 684-689.

7. Barredo JC, Hastings C, Lu X, Devidas M, Chen Y, Armstrong D et al. (2017). Isolated late testicular relapse of B-cell acute lymphoblastic leukemia treated with intensive systemic chemotherapy and responsebased testicular radiation: A Children's Oncology Group study. Pediatr Blood Cancer. 65(5): e26928.

8. Bene MC, Castoldi G, Knapp W et al. (1995). Proposals for the immunological classification of acute leukaemias: European Group for the Immunological Characterization of Leukemias (EGIL) Leukemia 9: 17831786 .

9. Bessho F, Takayama N, Fronkova E, Zuna J. (2013). Reappearance of acute lymphoblastic leukemia 34 years after initial diagnosis: a case report and study of the origin of the reappeared blasts. Int $\mathrm{J}$ Hematol. 97(4): 525-528.

10. Bhatia S. (2013). Therapy-related myelodysplasia and acute myeloid leukemia. Semin Oncol. 40(6): 666-675.

11. Bien E, Stachowicz-Stencel T, Szalewska M, Krawczyk M, Synakiewicz A, Dubaniewicz-Wybieralska M et al. (2009). Poor-risk high-grade gliomas in three survivors of childhood acute lymphoblastic leukaemia - an overview of causative factors and possible therapeutic options. Childs Nerv Syst. 25(5): 619-626.

12. Bierings M, Szczepanski T, van Wering ER, Willemse MJ, Langerak AW, Revesz T et al. (2001). Two consecutive immunophenotypic switches in a child with immunogenotypically stable acute leukaemia. Br J Haematol. 113(3): 757-762.
13. Borowitz MJ, Bene M-C, Harris NL, Porwit A, Matutes E. (2008). Acute leukemias of ambiguous lineage. In: Swerdlow SH, Campo E, Harris NL, Jaffe ES, Pileri SA, Stein $\mathrm{H}$ et al., editors. WHO Classification of Tumours of Haematopoietic and Lymphoid Tissues. Geneva: WHO Press: $150-151$.

14. Borowitz MJ, Chan JKC. (2008). B lymphoblastic leukaemia/lymphoma with recurrent genetic abnormalities. In: Swerdlow SH, Campo E, Harris $\mathrm{NL}$, Jaffe ES, Pileri SA, Stein $\mathrm{H}$ et al., editors. WHO Classification of Tumours of Haematopoietic and Lymphoid Tissues. Geneva: WHO Press: $171-175$

15. Borowitz MJ, Chan JKC. (2008). B lymphoblastic leukaemia/lymphoma, not otherwise specified. In: Swerdlow SH, Campo E, Harris NL, Jaffe ES, Pileri SA, Stein H et al., editors. WHO Classification of Tumours of Haematopoietic and Lymphoid Tissues. Geneva: WHO Press: 168-170.

16. Borowitz MJ, Chan JKC. (2008). T Iymphoblastic leukemia/lymphoma. In: Swerdlow SH, Campo E, Harris NL, Jaffe ES, Pileri SA, Stein H et al., editors. WHO Classification of Tumours of Haematopoietic and Lymphoid Tissues. Geneva: WHO Press: 176-178.

17. Conter V, Bartram CR, Valsecchi MG, Schrauder A, Panzer-Grumayer R, Moricke $A$ et al. (2010). Molecular response to treatment redefines all prognostic factors in children and adolescents with B-cell precursor acute lymphoblastic leukemia: results in 3184 patients of the AIEOPBFM ALL 2000 study. Blood. 115: 3206-3214.

18. Donadieu J, Auclerc MF, Baruchel A et al. (1998). Critical study of prognostic factors in childhood acute lymphoblastic leukemia: differences in outcome are poorly explained by the most significant prognostic variables. FRALLE Group Frensh Acute Lymphoblastic Leukemia study group. Br.J.Haematol. 102: 729-739.

19. Dordelmann M, Reiter A, Borkhardt A, Ludwig WD. (1999). Prednisone response in the strongest predictor of treatment outcome in infant acute lymphoblastic leukemia. Blood. 94(4): 1209-1217.

20. Dreyer ZE, Hilden JM, Jones TL, Devidas M, Winick NJ, Willman CL et al. (2015). Intensified chemotherapy without SCT in infant ALL: results from COG P9407 (Cohort 3). Pediatr Blood Cancer. 62: 419-426.

21. Erduran E, Gedik Y, Orhan F et al. (1999). Brief report. Leukemic infiltrations of the peritoneum at diagnosis and the breast at relapse in a child with acute B-cell lymphoblastic leukemia. Med Pediatr Oncol. 32: $71-72$.

22. Fink FM, Koller U, Mayer $\mathrm{H}$ et al. (1993). Prognostic significance of myeloid-associated antigen expression on blast cells in children with acute lymphoblastic leukemia. Med PediatrOncol. 21: $340-346$.

23. Firat H, Favier R, Adam M et al. (2001). Determination of myeloid antigen expression on childhood acute lymphoblastic leukaemia cells: discrepancies using different monoclonal antibody clones. Leuk Lymphoma. 42(4): 675-682.

24. Fisher KE, Hsu AP, Williams CL, Sayeed H, Merritt BY, Elghetany MT, Holland SM, Bertuch AA, Gramatges MM. (2017). Somatic mutations in chil- 
dren with GATA2-associated myelodysplastic syndrome who lack other features of GATA2 deficiency. Blood Adv. 1(7): 443-448.

25. Griffin TC, Shuster JJ, Buchanan GR et al. (2000). Slow disapperarance of periferall blood blasts in as adverse prognostic factor in childhood T cell acute lymphoblastic leukemia: a Pedoatric Oncology Group study. Leukemia. 14(5): 792-795.

26. Haarman EG, Kaspers G-JP, Veerman AJP. (2003). Glucocorticoid resistence in childhood leuaemia: mechanisms and modulation. $\mathrm{Br} \mathrm{J}$ Haematol. 120(6): 919-929.

27. Haddy TB, Mosher RB, Reaman GH. (2009). Late effects in long-term survivors after treatment for childhood acute leukemia. Clin Pediatr (Phila). 48(6): 601-608.

28. Hannson CA, Abaza M, Sheldon S et al. (1993). Acute biphenotypic leukemia: immunophenotypic and cytogenetic analysis. $\mathrm{Br} \mathrm{J}$ Haematol. 84(1): 49-60.

29. Howard MR, Thomas L, Reid MM. (1994). Variable detection antigen in childhood acute lymphoblastic leukemia. J Clin Patology. 47: $1006-1009$.

30. Hunger SP, Lu X, Devidas M, Camitta BM, Gaynon PS, Winick NJ et al. (2012). Improved survival for children and adolescents with acute lymphoblastic leukemia between 1990 and 2005: a report from the children's oncology group. J Clin Oncol. 30: 1663-1669.

31. Janka-Schaub GE, Stuhrk H, Kortam B et al. (1991). Initiales Ansprechen au die Therapie als wichtigster prognostischer Factor bei der akuten lymphoblastischen Leukamia in Kindesalter. Klin. Padiatr. 203(4): 231-235.

32. Kachel L, Rudzka E, Krzemien S et al. (1995). Wznowy w osrodkowym ukladzie nerwowym w przebiegu ostrej bialaczki limfoblastycznej a sposob postepowania profilaktycznego. Acta Haematologica Polonica (Poland). 26(1): 47-56.

33. Karrman K, Johansson B. (2017). Pediatric T-cell acute lymphoblastic leukemia. Genes Chromosomes Cancer. 56(2): 89-116

34. Khan M, Siddiqi R, Naqvi K. (2018). An update on classification, genetics, and clinical approach to mixed phenotype acute leukemia (MPAL). Ann Hematol. (Epub ahead of print).

35. Killick S, Matutes E, Powles RL, Hamblin M, Swansbury J, Treleaven JG et al. (1999). Outcome of biphenotypic acute leukemia. Haematologica. 84(8): 699-706.

36. Krawczuk-Rybak M, Zak J, Jaworowska B. (2003). A lineage switch from AML to ALL with persistent translocation $\mathrm{t}(4 ; 11)$ in congenital leukemia. Med Pediatr Oncol. 41(1): 95-96.

37. Kurec AS, Belair P, Stefanu C et al. (1991). Significance of aberrant immunophenotypes in childhood acute lymphoblastic leukemia. Cancer. 67: 3081.

38. Lawson SE, Harrison G, Richards S et al. (2000). The UK experience in treating relapsed childhood acute lymphoblastic leukemia: a report on the Medical Research Coucil UKALLR1 study. Br J Haematol. 108(3): 531-543.

39. Le Clerc JM, Billett AL, Gelber RD et al. (2002). Treatment of childhood acute lymphoblastic leukemia: result of Dana-Farber ALL Consorcium Protocol 87-01. J Clin Oncology. 20(1): 237-246.

40. Lee JW, Kim SK, Jang PS, Jeong DC, Chung NG, Cho B et al. (2016). Treatment of children with acute lymphoblastic leukemia with risk group based intensification and omission of cranial irradiation: A Korean study of 295 patients. Pediatr Blood Cancer. 63: 1966-1973.

41. Lee JW, Cho B. (2017). Prognostic factors and treatment of pediatric acute lymphoblastic leukemia. Korean $\mathrm{J}$ Pediatr. 60(5): 129-137.

42. Legrand O, Perrot JY, Simonin G et al. (1998). Adult biphenotypic acute leukemia: an ently with poor prognosis which is related to unfavorable cytogenetics and P-glycoprotein over-expression. $\mathrm{Br} \mathrm{J}$ Haematol. 100(1): $147-155$

43. Lo Coco F. (1991). Hybrid phenotypes and lineage promiscuity in acute leukemia. Haematologica. 76(3): 215-225.

44. Loning L, Zimmermann M, Reiter A et al. (2000). Secondary neoplasms subsequent to Berlin-Frankfurt-Munster therapy of acute lymphoblastic leukemia in childhood: significantly lower risk without cranial therapy. Blood. 95: 2770-2775.
45. Ludwig WD, Thiel E, Koller U et al. (1990). Incindence and clinical implications of acute hybrid leukemia in childhood. Haematol.Blood Transfus. (Acute Leukemias II): 516-522.

46. Madeja G. (1994). Chemioterapia onkologiczna doroslych i dzieci Pod redakcja G. Madeja - Warszawa: Wydawnictwo Lekarskie PZWL: 315.

47. Matsuzaki A, Okamura J, Ishii E et al. (1999). Treatment of standard-risk acute lymphoblastic leukemia in children: The results of Protocol AL 841 from the Kyushu-Yamaguchi Children's Cancer Study Group in Japan. Pediatr Hematol Oncol. 16: 187-199.

48. Mejstrikova E, Kalina T, Trka J, Stary J, Hrusak O. (2005). Correlation of CD33 with poorer prognosis in childhood ALL implicates a potential of anti-CD33 frontline therapy. Leukemia. 19(6): 1092-1094.

49. Mejstrikova E, Volejnikova J, Fronkova E, Zdrahalova K et al. (2010). Prognosis of children with mixed phenotype acute leukemia treated on the basis of consistent immunophenotypic criteria. Haematologica. 95(6): 928-935.

50. Mi Y, Bian S, Meng Q et al. (2000). Study on the clinical characteristics of biphenotypic acute leukemia. Zhonghua Xue Ye Za Zhi. 21(7): 352-354.

51. Miller RW, Young JL, Novakovic B. (1995). Childhood cancer. Cancer. 75: 395-405.

52. Moricke A, Zimmermann M, Reiter A, Henze G, Schrauder A, Gadner H et al. (2010). Long-term results of five consecutive trials in childhood acute lymphoblastic leukemia performed by the ALL-BFM study group from 1981 to 2000. Leukemia. 24: 265-284

53. Nachman JB, Heerema NA, Sather $\mathrm{H}$ et al. (2007). Outcome of treatment in children with hypodiploid acute lymphoblastic leukemia. Blood. 110: 1112-1115.

54. Neglia JP, Friedman DL, Yasui Y et al. (2001). Second Malignant Neoplasms in Five-Year Survivors of Childhood Cancer: Childhood Cancer Survivor Study. JNCI J Natl Cancer Inst. 93(8): 618-629.

55. Neglia JP, Meadows AT, Robison LL et al. (1991). Second neoplasms after acute lymphoblastic leukemia in childhood. $\mathrm{N}$ Engl $\mathrm{J}$ Med. 325(19): 1330-1336.

56. Neglia JP, Robison LL, Stovall M et al. (2006). New Primary Neoplasms of the Central Nervous System in Survivors of Childhood Cancer: a Report From the Childhood Cancer Survivor Study. JNCI J Natl Cancer Inst. 98(21): 1528-1537.

57. Ng SM, Ariffin WA, Lin HP et al. (2000). Clinical features and treatment outcome of children with myeloid antigen coexpression in B-lineage acute lymphoblastic leukemia: a study of 151 Malaysian children. J Trop Pediatr. 46(2): 73-78.

58. Nielsen SN, Eriksson F, Rosthoej S, Andersen MK, Forestier E, Hasle H Hjalgrim LL, Aasberg A, Abrahamsson J, Heyman M, Jonsson OG, Pruunsild K, Vaitkeviciene GE, Vettenranta K, Schmiegelow K. (2017). Children with low-risk acute lymphoblastic leukemia are at highest risk of second cancers. Pediatr Blood Cancer. 64(10).

59. Otsubo K, Yabe M, Yabe H, Fukumura A, Morimoto T, Kato M, Mochizuki H. (2016). Successful acute lymphoblastic leukemia-type therapy in two children with mixed-phenotype acute leukemia. Pediatr Int. 58(10): 1072-1076.

60. Owaidah TM, Al Beihany A, lqbal MA, Elkum N, Roberts GT. (2006). Cytogenetics, molecular and ultrastructural characteristics of biphenotypic acute leukemia identified by the EGIL scoring system. Leukemia. 20(4): 620-626.

61. Pieters R, Schrappe M, De Lorenzo P, Hann I, De Rossi G, Felice M et al. (2007). A treatment protocol for infants younger than 1 year with acute lymphoblastic leukaemia (Interfant-99): an observational study and a multicentre randomised trial. Lancet. 370: 240-250.

62. Pituch-Noworolska A, Gawlicka M, Balwierz W et al. (1997). Atypical phenotypes of leukemic cells in acute leukaemia in children. Acta Haematologica Polonica (Poland). 28(1): 53-63.

63. Pui CH, Campana D, Pei D, Bowman WP, Sandlund JT, Kaste SC et al. (2009). Treating childhood acute lymphoblastic leukemia without cranial irradiation. N Engl J Med. 360: 2730-2741.

64. Pui CH, Raimondi SC, Head DR et al. (1991). Characterization of childhood acute lymphoblastic leukemia with multiple 
myeloid and lymphoid markers at diagnosis and relaps. Blood. 78 1327-1337.

65. Pui $\mathrm{CH}$, Yang JJ, Hunger SP, Pieters R, Schrappe M, Biondi A et al. (2015). Childhood Acute Lymphoblastic Leukemia: Progress Through Collaboration. J Clin Oncol. 33(27): 2938-2948.

66. Pui CH. (1998). Acute lymphoblastic leukemia. N Engl J Medicine. 339(9): 605-615.

67. Putti MC, Rondelli R, Cocoto MG et al. (1998). Expression of myeloid markers lacks prognostic impact in children treated for acute lymphoblastic leukemia: Italian experience in AIEOP-ALL 88-91 stidies. Blood. 92 795-801.

68. Reiter A, Schrappe M, Ludwig WD et al. (1994). Chemotherapy in 998 unselected childhood acute lymphoblastic leukemia patients Result and conclusions of the multicenter trial ALL-BFM 86. Blood. 84: $3122-3133$

69. Riehm H, Reiter A, Schrappe M et al. (1987). Corticosteroid-dependent reduction of leucocyte count in blood as a prognostic factor in acute lymphoblastic leukemia in childhood (therapy study ALL-BFM 83). Klinische Padiatrie. 199: 151-160.

70. Rihani R, Bazzeh F, Faqih N, Sultan I. (2010). Secondary hematopoietic malignancies in survivors of childhood cancer: an analysis of 111 cases from the Surveillance, Epidemiology, and End Result-9 registry. Cancer. 116(18): 4385-4394.

71. Rubnitz JE, Onciu M, Pounds S, Shurtleff S, Cao X, Raimondi SC et al (2009). Acute mixed lineage leukemia in children: the experience of St. Jude Children's Research Hospital. Blood. 113(21): 5083-5089.

72. Salek C, Folber F, Fronkova E, Prochazka B, Marinov I, Cetkovsky P, Mayer J, Doubek M; Czech Leukemia Study Group - for Life. (2016) Early MRD response as a prognostic factor in adult patients with acute lymphoblastic leukemia. Eur J Haematol. 96(3): 276-284.

73. Schmiegelow K, Levinsen MF, Attarbaschi A, Baruchel A, Devidas M et al. (2013). Second malignant neoplasms after treatment of childhood acute lymphoblastic leukemia. J Clin Oncol. 31(19): 2469-2476.

74. Schrappe M, Reiter A, Sauter S und andere. (1994). Konzeption und Zwischenergebnis der Therapiestudie ALL-BFM 90 zur Behandlung der akuten lympphoblastischen Leukamie bei Kindern und Jugendlichen: Die Behandlung des initialen Therapieansprechens in Blut und Knochenmark. Klin Padiatr. 206: 208-221.

75. Schrappe M, Reiter A, Zimmermann M et al. (2000). Long-term result of four consecutiwve trials in childhood ALL perfomed by the ALL-BFM study group from 1981 to 1995. Berlin-Frankfurt-Munster. Leukemia. 14(12): 2205-2222.

76. Schrappe M, Valsecchi MG, Bartram CR, Schrauder A, Panzer-Grumayer R, Moricke A et al. (2011). Late MRD response determines relapse risk overall and in subsets of childhood T-cell ALL: results of the AIEOPBFM-ALL 2000 study. Blood. 118: 2077-2084.

77. Stary J, Zimmermann M, Campbell M, Castillo L et al. (2014). Intensive Chemotherapy for Childhood Acute Lymphoblastic Leukemia: Results of the Randomized Intercontinental Trial ALL IC-BFM 2002. J Clin Oncol. 32: $174-185$.

78. Stiller CA, Parkin DM. (1996). Geographic and ethnic variations in the incidence of childhood cancer. Br Med Bull. 52: 682-703.

79. Theunissen P, Mejstrikova E, Sedek L, van der Sluijs-Gelling AJ, Gaipa G, Bartels M, Sobral da Costa E, Kotrova M et al.; EuroFlow Consortium. (2017). Standardized flow cytometry for highly sensitive MRD measurements in B-cell acute lymphoblastic leukemia. Blood. 129(3): 347-357.

80. Trigg ME, Steinherz PG, Chappell R et al. (2000). Early testicular biopsy in males with acute lymphoblastic leukemia: lack of impact on subsequent event-free survival. J Pediatr Hematol Oncol. 22(1): 27-33.

81. Tsuruchi N, Okamura J. (1996). Childhood acute lymphoblastic leukemia relapse in the uterine cervix. J Pediatr Hematol Oncol. 18(3): 311-313.

82. Tzortzatou-Stathopoulou F, Papadopoulou AL, Moschovi M, Botsonis A, Tsangaris GT. (2001). Low relapse rate in children with acute lymphoblastic leukemia after risk-directed therapy. J Pediatr Hematol Oncol. 23(9): 591-597.

83. Uckun FM, Sather HN, Gaynon PS. (1997). Clinical features and treatment outcome of children with myeloid antigen positive acute lymphoblastic leukemia: a report from the Children's Cancer Group. Blood. 90(1): $28-35$

84. Volejnikova J, Mejstrikova E, Valova T, Reznickova L, Hodonska L, Miha V, Sterba J, Jabali Y, Prochazkova D, Blazek B, Hak J, Cerna Z, Hrusak O, Stary J, Trka J, Fronkova E. (2011). Minimal residual disease in peripheral blood at day 15 identifies a subgroup of childhood B-cell precursor acute lymphoblastic leukemia with superior prognosis. Haematologica. 96(12): 1815-1821.

85. Vora A, Andreano A, Pui CH, Hunger SP, Schrappe M, Moericke A, Biondi A et al. (2016). Influence of Cranial Radiotherapy on Outcome in Children with Acute Lymphoblastic LeukemiaTreated with Contemporary Therapy. J Clin Oncol. 34(9): 919-926.

86. Vrooman LM, Neuberg DS, Stevenson KE, Asselin BL, Athale UH, Clavell $L$ et al. (2011). The low incidence of secondary acute myelogenous leukaemia in children and adolescents treated with dexrazoxane for acute lymphoblastic leukaemia: a report from the Dana-Farber Cancer Institute ALL Consortium. Eur J Cancer. 47(9): 1373-1379.

87. Weir EG, Ali Ansari-Lari M, Batista DA, Griffin CA, Fuller S, Smith BD et al. (2007). Acute bilineal leukemia: a rare disease with poor outcome. Leukemia. 21(11): 2264-2270.

88. Weir EG, Borowitz MJ. (2001). Flow cytometry in the diagnosis of acute leukemia. Semin Hematol. 38(2): 124-138.

89. Wiersma S, Ortega J, Sobel E et al. (1991). Clinical importance of myeloid antigen expression in acute lymphoblastic leukemia of childhood. N Engl J Med. 324: 800-808.

90. Yeoh AE, Ariffin H, Chai EL, Kwok CS, Chan YH, Ponnudurai $\mathrm{K}$ et al. (2012). Minimal residual disease-guided treatment deintensification for children with acute lymphoblastic leukemia: results from the MalaysiaSingapore acute lymphoblastic leukemia 2003 study. J Clin Oncol. 30: 2384-392.

\section{Сведения об авторах:} Дорош Ольга Игоревна - К.мед.н., врач-гематолог детский отделения гематологии и интенсивной химиотерапии и отделения консультативной поликлиники Коммунального неком-
мерческого предприятия Львовского областного совета «Западноукраинский специализированный детский медицинский центр». Адрес: г. Львов, ул. Днестровская, 27. мерческого предприятия Львовского областного совета «Западноукраинский специализированный детский медицинский центр». Адрес: г. Львов, ул. Днестровская, 27. цимбалюк-Волошин Ирина Петровна - К.мед.н., зав. отделения гематологии и интенсивной химиотерапии и анестезиолог отделения анестезиологии и интенсивной терапии Комсфузионной медицины ФПДО Львовского НМУ имени Д. Галицкого. Адрес: г. Львов, ул. Днестровская, 27.

Бодак Христина Игоревна - врач-гематолог детский отделения гематологии и интенсивной химиотерапии Коммунального некоммерческого предприятия Львовского областного совета «Западноукраинский специализированный детский медицинский центр». Адрес: г. Львов, ул. Днестровская, 27.

Полищук Романа Степановна - к.мед.н., врач-гематолог детский отделения гематологии и интенсивной химиотерапии и отделения консультативной поликлиники Коммунального некоммерческого предприятия Львовского областного совета «Западноукраинский специализированный детский медицинский центр». Адрес: г. Львов, ул. Днестровская, 27. Степанюк Алла Ивановна - врач-гематолог детский отделения гематологии и интенсивной химиотерапии и анестезиолог отделения анестезиологии и интенсивной терапии Коммунальнобель Оксана Ивановна - врач-гематолог детский отделения гематологии и интенсивной химиотерапии Коммунального некоммерческого предприятия Львовского областного совета «Западноукраинский специализированный детский медицинский центр». Адрес: г. Львов, ул. Днестровская, 27.

Скоропад Лариса Львовна - врач-гематолог детский отделения гематологии и интенсивной химиотерапии и отделения консультативной поликлиники Коммунального некоммерческого предприятия Львовского областного совета «Западноукраинский специализированный детский медицинский центр». Адрес: г. Львов, ул. Днестровская, 27. Трояновськая Ольга Орестовна - к.мед.н., ассистент каф. педиатрии Львовского НМУ имени Д. Галицкого, врач-гематолог детский отделения гематологии и интенсивной химиоте作 зированный детский медицинский центр». Адрес: г. Львов, ул. Днестровская, 27.

Козлова Елена Игоревна - врач-гематолог етский отделения гематологи и интенсивной химиотерапии Коммунального некоммерческого предприятия Львовского областного совета «Западноукраинский специализированный детский медицинский центр». Адрес: г. Львов, ул. Днестровская, 27.

Мих Алла Николаевна - врач-цитолог клинической лаборатории Коммунального некоммерческого предприятия Львовского областного совета «Западноукраинский специализированный детский медицинский центр». Адрес: г. Львов, ул. Днестровская, 27; Медицинский центр Святой Параскевы. Адрес: г. Львов, ул. Заводская, 7. Середич Лилия Петровна - врач-цитолог клинической лаборатории Коммунального некоммерческого предприятия Львовского областного совета «Западноукраинский специализированный детский медицинский центр». Адрес: г. Львов, ул. Днестровская, 27.

Глинськая Оксана Владимировна - зав. отделения клинической лаборатории Коммунального некоммерческого предприятия Львовского областного совета «Западноукраинский спе-

Статья поступила в редакцию 02.08.2018 г., принята к печати 04.12.2018 г. 